\title{
A new mechanism for atmospheric mercury redox chemistry: implications for the global mercury budget
}

\author{
Hannah M. Horowitz ${ }^{1}$, Daniel J. Jacob ${ }^{1,2}$, Yanxu Zhang ${ }^{2}$, Theodore S. Dibble ${ }^{3}$, Franz Slemr ${ }^{4}$, Helen M. Amos ${ }^{2}$, \\ Johan A. Schmidt ${ }^{2,5}$, Elizabeth S. Corbitt ${ }^{1}$, Eloïse A. Marais ${ }^{2}$, and Elsie M. Sunderland ${ }^{2,6}$ \\ ${ }^{1}$ Department of Earth \& Planetary Sciences, Harvard University, Cambridge, MA, USA \\ ${ }^{2}$ Harvard John A. Paulson School of Engineering and Applied Sciences, Harvard University, Cambridge, MA, USA \\ ${ }^{3}$ Chemistry Department, State University of New York - Environmental Science and Forestry, Syracuse, NY, USA \\ ${ }^{4}$ Max Planck Institute for Chemistry (MPI-C), Department of Atmospheric Chemistry, Mainz, Germany \\ ${ }^{5}$ Department of Chemistry, University of Copenhagen, Universitetsparken 5, 2100 Copenhagen O, Denmark \\ ${ }^{6}$ Department of Environmental Health, T. H. Chan School of Public Health, Harvard University, Boston, MA, USA
}

Correspondence to: Hannah M. Horowitz (hmhorow@post.harvard.edu)

Received: 23 December 2016 - Discussion started: 17 January 2017

Revised: 20 April 2017 - Accepted: 26 April 2017 - Published: 29 May 2017

\begin{abstract}
Mercury $(\mathrm{Hg})$ is emitted to the atmosphere mainly as volatile elemental $\mathrm{Hg}^{0}$. Oxidation to water-soluble $\mathrm{Hg}^{\mathrm{II}}$ plays a major role in $\mathrm{Hg}$ deposition to ecosystems. Here, we implement a new mechanism for atmospheric $\mathrm{Hg}^{0} / \mathrm{Hg}^{\mathrm{II}}$ redox chemistry in the GEOS-Chem global model and examine the implications for the global atmospheric $\mathrm{Hg}$ budget and deposition patterns. Our simulation includes a new coupling of GEOS-Chem to an ocean general circulation model (MIT$\mathrm{gcm}$ ), enabling a global 3-D representation of atmosphereocean $\mathrm{Hg}^{0} / \mathrm{Hg}^{\mathrm{II}}$ cycling. We find that atomic bromine $(\mathrm{Br})$ of marine organobromine origin is the main atmospheric $\mathrm{Hg}^{0}$ oxidant and that second-stage $\mathrm{HgBr}$ oxidation is mainly by the $\mathrm{NO}_{2}$ and $\mathrm{HO}_{2}$ radicals. The resulting chemical lifetime of tropospheric $\mathrm{Hg}^{0}$ against oxidation is 2.7 months, shorter than in previous models. Fast $\mathrm{Hg}^{\mathrm{II}}$ atmospheric reduction must occur in order to match the $\sim 6$-month lifetime of $\mathrm{Hg}$ against deposition implied by the observed atmospheric variability of total gaseous mercury $\left(\mathrm{TGM} \equiv \mathrm{Hg}^{0}+\mathrm{Hg}^{\mathrm{II}}(\mathrm{g})\right)$. We implement this reduction in GEOS-Chem as photolysis of aqueous-phase $\mathrm{Hg}^{\mathrm{II}}$-organic complexes in aerosols and clouds, resulting in a TGM lifetime of 5.2 months against deposition and matching both mean observed TGM and its variability. Model sensitivity analysis shows that the interhemispheric gradient of TGM, previously used to infer a longer $\mathrm{Hg}$ lifetime against deposition, is misleading because Southern Hemisphere $\mathrm{Hg}$ mainly originates from oceanic emissions rather than transport from the Northern Hemisphere.
\end{abstract}

The model reproduces the observed seasonal TGM variation at northern midlatitudes (maximum in February, minimum in September) driven by chemistry and oceanic evasion, but it does not reproduce the lack of seasonality observed at southern hemispheric marine sites. Aircraft observations in the lowermost stratosphere show a strong TGM-ozone relationship indicative of fast $\mathrm{Hg}^{0}$ oxidation, but we show that this relationship provides only a weak test of $\mathrm{Hg}$ chemistry because it is also influenced by mixing. The model reproduces observed $\mathrm{Hg}$ wet deposition fluxes over North America, Europe, and China with little bias (0-30\%). It reproduces qualitatively the observed maximum in US deposition around the Gulf of Mexico, reflecting a combination of deep convection and availability of $\mathrm{NO}_{2}$ and $\mathrm{HO}_{2}$ radicals for second-stage $\mathrm{HgBr}$ oxidation. However, the magnitude of this maximum is underestimated. The relatively low observed $\mathrm{Hg}$ wet deposition over rural China is attributed to fast $\mathrm{Hg}^{\mathrm{II}}$ reduction in the presence of high organic aerosol concentrations. We find that $80 \%$ of $\mathrm{Hg}^{\mathrm{II}}$ deposition is to the global oceans, reflecting the marine origin of $\mathrm{Br}$ and low concentrations of organic aerosols for $\mathrm{Hg}^{\mathrm{II}}$ reduction. Most of that deposition takes place to the tropical oceans due to the availability of $\mathrm{HO}_{2}$ and $\mathrm{NO}_{2}$ for second-stage $\mathrm{HgBr}$ oxidation. 


\section{Introduction}

Atmospheric mercury $(\mathrm{Hg})$ cycles between two stable redox forms, elemental $\left(\mathrm{Hg}^{0}\right)$ and divalent $\left(\mathrm{Hg}^{\mathrm{II}}\right)$. Most $\mathrm{Hg}$ emissions are as gaseous elemental $\mathrm{Hg}^{0}$, which is relatively inert and sparingly soluble in water. $\mathrm{Hg}^{0}$ is oxidized in the atmosphere to $\mathrm{Hg}^{\mathrm{II}}$ by loss of its two $6 s^{2}$ electrons. $\mathrm{Hg}^{\mathrm{II}}$ salts are water-soluble, partition into the aerosol, and are efficiently removed from the atmosphere by wet and dry deposition, but they can also be reduced back to $\mathrm{Hg}^{0}$. Understanding atmospheric $\mathrm{Hg}$ redox chemistry is critical for determining where $\mathrm{Hg}$ will be deposited globally. Here we propose an updated $\mathrm{Hg}^{0} / \mathrm{Hg}^{\mathrm{II}}$ redox mechanism, incorporating recent kinetic data and other observational constraints, for use in atmospheric models. We implement the mechanism in the GEOS-Chem global model (Bey et al., 2001; Holmes et al., 2010) and examine the implications for the global atmospheric $\mathrm{Hg}$ budget and deposition patterns.

Previous work assumed gas-phase $\mathrm{OH}$ and ozone to be the dominant $\mathrm{Hg}^{0}$ oxidants (Bergan and Rodhe, 2001; Dastoor and Larocque, 2004; Selin et al., 2007; Bullock et al., 2008; Travnikov and Ilyin, 2009; De Simone et al., 2014; Gencarelli et al., 2014). It is now well established that the corresponding $\mathrm{HgOH}$ and $\mathrm{HgO}$ products are too thermally unstable to enable oxidation to $\mathrm{Hg}^{\mathrm{II}}$ under atmospheric conditions (Shepler and Peterson, 2003; Goodsite et al., 2004; Calvert and Lindberg, 2005; Hynes et al., 2009; Jones et al., 2016). OH and ozone could still potentially be important oxidants on aerosols (Ariya et al., 2015). The importance of $\mathrm{Br}$ atoms for $\mathrm{Hg}^{0}$ oxidation was first recognized to explain atmospheric mercury depletion events occurring in the Arctic boundary layer in spring (Schroeder et al., 1998), where sea salt photochemistry provides a large Br source (Fan and Jacob, 1992; Steffen et al., 2008; Simpson et al., 2015). Oxidation of $\mathrm{Hg}^{0}$ to $\mathrm{Hg}^{\mathrm{II}}$ by $\mathrm{Br}$ is a two-stage exothermic mechanism whereby the second-stage conversion of $\mathrm{HgBr}$ to $\mathrm{Hg}^{\mathrm{II}}$ can be carried out by a number of radical oxidants (Goodsite et al., 2004; Dibble et al., 2012). Holmes et al. (2006) first suggested $\mathrm{Br}$ atoms could be the main $\mathrm{Hg}^{0}$ oxidant on a global scale, with $\mathrm{Br}$ originating principally from photochemical decomposition of bromoform emitted by phytoplankton (Yang et al., 2005). More recent observations of background tropospheric $\mathrm{BrO}$ point to ubiquitous $\mathrm{Br}$ radical chemistry in the troposphere (Theys et al., 2011; Wang et al., 2015). Recent aircraft observations of $\mathrm{Hg}^{\mathrm{II}}$ and $\mathrm{BrO}$ over the southeastern US are consistent with $\mathrm{Br}$ atoms acting as the main $\mathrm{Hg}^{0}$ oxidant (Gratz et al., 2015; Shah et al., 2016).

Atmospheric $\mathrm{Hg}^{\mathrm{II}}$ can be deposited or alternatively reduced back to $\mathrm{Hg}^{0}$. Competition between these two processes determines the global patterns of $\mathrm{Hg}$ deposition as well as the regional fate of $\mathrm{Hg}^{\mathrm{II}}$ emitted directly by combustion. Atmospheric reduction mechanisms for $\mathrm{Hg}^{\mathrm{II}}$ are poorly understood, but photoreduction in aquatic systems has been widely observed (Costa and Liss, 1999; Amyot et al., 2000; Mason et al., 2001). Fast in-plume reduction of $\mathrm{Hg}^{\mathrm{II}}$ emitted by coal-fired power plants was first reported by Edgerton et al. (2006) and Lohman et al. (2006), but more recent field observations suggest that on average only $5 \%$ (range $0-55 \%$ ) of emitted $\mathrm{Hg}^{\mathrm{II}}$ is reduced in the plume (Deeds et al., 2013; Landis et al., 2014). Recent aircraft observations (Weigelt et al., 2016) and emission inventories (Zhang et al., 2016) suggest that previous reports of in-plume reduction of $\mathrm{Hg}^{\mathrm{II}}$ may reflect in part an overestimate of $\mathrm{Hg}^{\mathrm{II}}$ emissions.

The speciation of atmospheric $\mathrm{Hg}^{\mathrm{II}}$ is unknown (Jaffe et al., 2014; Gustin et al., 2015; Jones et al., 2016). It is generally assumed from chemical equilibrium considerations that the main $\mathrm{Hg}^{\mathrm{II}}$ species are $\mathrm{HgCl}_{2}$ in the gas phase and $\mathrm{Hg}_{-}$ chloride complexes in the aqueous phase (Hedgecock and Pirrone, 2001; Selin et al., 2007; Holmes et al., 2009). Hgchloride complexes are relatively resistant to photoreduction (Allard and Arsenie, 1991; Pehkonen and Lin, 1998). HgII also strongly binds to organic ligands, including to reduced sulfur complexes and carboxyl groups (Pehkonen and Lin, 1998; Haitzer et al., 2002; Ravichandran, 2004; Zheng and Hintelmann, 2009). Photoreduction of $\mathrm{Hg}^{\mathrm{II}}$ bound to dissolved organic carbon (DOC) and other organic matter has been widely reported in aquatic environments (Amyot et al., 1994; Xiao et al., 1995; O'Driscoll et al., 2006; Whalin and Mason, 2006) and could also possibly take place in organic aerosols (OA). Bash et al. (2014) found that including incloud aqueous photoreduction via organic acids based on the mechanism proposed by Si and Ariya (2008) improved the simulation of $\mathrm{Hg}$ wet deposition in their regional air quality model. Observed photochemically driven shifts in the abundance of naturally occurring $\mathrm{Hg}$ isotopes in the atmosphere and precipitation support the occurrence of aqueous-phase photoreduction involving $\mathrm{Hg}^{\mathrm{II}}$-organic complexes (Gratz et al., 2010; Sonke, 2011; Sonke et al., 2015).

The GEOS-Chem model is widely used for global studies of atmospheric chemistry and has been applied in particular to simulations of atmospheric $\mathrm{Hg}$ and biogeochemical cycling with a focus on interpreting observations (e.g., Strode et al., 2008; Weiss-Penzias et al., 2015; Zhang et al., 2016). The $\mathrm{Hg}$ chemical mechanism in the current standard version of GEOS-Chem (www.geos-chem.org) is based on Holmes et al. (2010). Our updated mechanism includes more recent information and is applied here with an improved GEOS-Chem simulation of halogen chemistry (Schmidt et al., 2016). As part of this work, we also introduce a new coupling of GEOSChem to a global 3-D ocean model (Y. X. Zhang et al., 2015) to better interpret observed seasonal variations of atmospheric $\mathrm{Hg}$ in the context of both atmospheric chemistry and oceanic drivers of air-sea exchange (Soerensen et al., 2013).

\section{Chemical mechanism}

Table 1 lists the new chemical mechanism implemented in GEOS-Chem. Table 2 lists reactions proposed in the litera- 
Table 1. Chemical mechanism for atmospheric mercury.

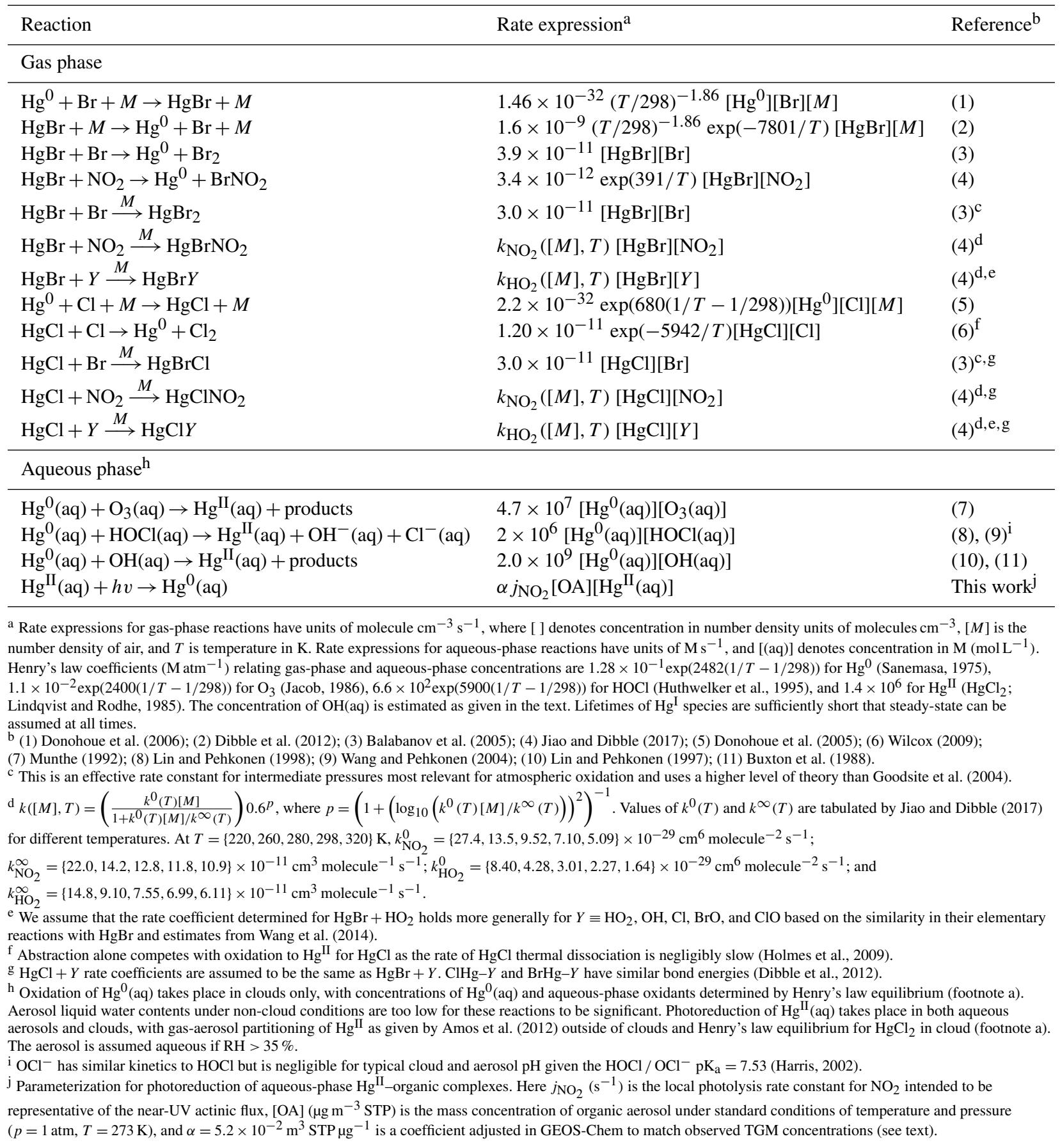

ture but subsequently estimated to be too slow to be of atmospheric relevance. Oxidation of $\mathrm{Hg}^{0}$ to $\mathrm{Hg}^{\mathrm{II}}$ in the gas phase involves a two-stage process (Reactions R1, R4) with competing Reactions (R2, R3):

$$
\begin{aligned}
& \mathrm{Hg}^{0}+X+M \rightarrow \mathrm{Hg}^{\mathrm{I}} X+M \\
& \mathrm{Hg}^{\mathrm{I}} X+M \rightarrow \mathrm{Hg}^{0}+X+M \\
& \mathrm{Hg}^{\mathrm{I}} X+Y \rightarrow \mathrm{Hg}^{0}+X Y
\end{aligned}
$$

$\mathrm{Hg}^{\mathrm{I}} X+Y+M \rightarrow \mathrm{Hg}^{\mathrm{II}} X Y+M$,

where $X$ is the first-stage $\mathrm{Hg}^{0}$ oxidant, $Y$ is the second-stage $\mathrm{Hg}^{\mathrm{I}}$ oxidant, and $M$ is a molecule of air (Goodsite et al., 2004; Donohoue et al., 2006; Dibble et al., 2012). The $\mathrm{Hg}^{\mathrm{I}}$ intermediate has a lifetime of less than a minute anywhere in the troposphere, so local steady state can be assumed. Goodsite et al. (2004) found that $\mathrm{HgBr}$ is sufficiently stable for the $\mathrm{Br}$ atom to be an effective first-stage $\mathrm{Hg}^{0}$ oxidant 
Table 2. Reactions not included in chemical mechanism ${ }^{\mathrm{a}}$.

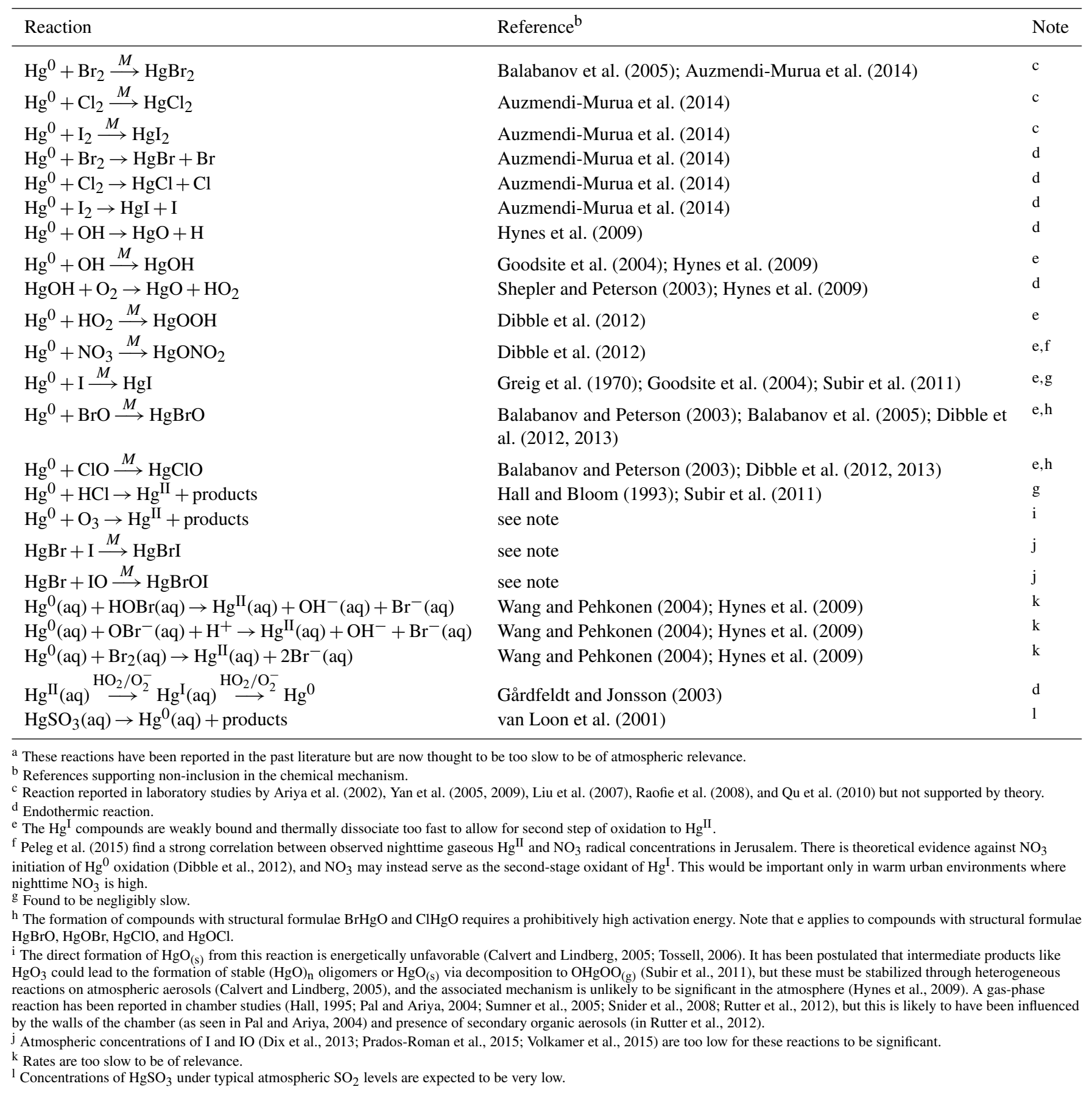

and proposed $Y \equiv \mathrm{OH}$ and $\mathrm{Br}$ as effective radicals to carry out the second stage of oxidation to $\mathrm{Hg}^{\mathrm{II}}$. The $\mathrm{Cl}$ atom can also oxidize $\mathrm{Hg}^{0}$ to produce $\mathrm{HgCl}$ (Balabanov and Peterson, 2003; Donohoue et al., 2005). Dibble et al. (2012) found that a broad range of radical oxidants could oxidize $\mathrm{HgBr}$ and $\mathrm{HgCl}$ including $Y \equiv \mathrm{NO}_{2}$ and $\mathrm{HO}_{2}$, the most abundant atmospheric radicals, as well as $Y \equiv \mathrm{BrO}, \mathrm{ClO}$, and $\mathrm{Cl}$. Other proposed first-stage gas-phase $\mathrm{Hg}^{0}$ oxidants appear to be unim- portant, including $\mathrm{OH}, \mathrm{O}_{3}, \mathrm{I}_{2} \mathrm{I}_{2}, \mathrm{Br}_{2}, \mathrm{Cl}_{2}, \mathrm{BrO}, \mathrm{ClO}, \mathrm{HCl}$, $\mathrm{HO}_{2}$, and $\mathrm{NO}_{3}$ (Table 2). $\mathrm{Hg}^{0}$ is sparingly soluble in water, but it has been suggested that fast aqueous-phase oxidation could take place in cloud droplets (Munthe and McElroy, 1992; Lin and Pehkonen, 1997, 1998; Whalin et al., 2007). We include these processes in our mechanism with $\mathrm{O}_{3}(\mathrm{aq})$, $\mathrm{HOCl}(\mathrm{aq})$, and $\mathrm{OH}(\mathrm{aq})$ as oxidants. 
Strong complexes between $\mathrm{Hg}^{\mathrm{II}}$ and organic acids may allow electrons to be transferred to $\mathrm{Hg}^{\mathrm{II}}$ during photolysis (Pehkonen and Lin, 1998). Gårdfeldt and Jonsson (2003) found that direct photolysis of $\mathrm{Hg}^{\mathrm{II}}$-oxalate resulted in $\mathrm{Hg}^{\mathrm{II}}$ reduction, and Si and Ariya (2008) reported the same for $\mathrm{Hg}^{\mathrm{II}}$-dicarboxylates. O'Driscoll et al. (2004) reported a linear increase in the efficiency of $\mathrm{Hg}^{\mathrm{II}}$ photoreduction in freshwater with increasing DOC concentrations. We assume here that $\mathrm{Hg}^{\mathrm{II}}$ photoreduction is dependent on the local concentration of $\mathrm{OA}$ and on the $\mathrm{NO}_{2}$ photolysis frequency $\left(\mathrm{j}_{2}\right)$ taken as a proxy for the UV actinic flux; we further assume the aerosol to be aqueous only at relative humidity greater than $35 \%$. The scaling factor $\alpha$ for the reaction (Table 1) is adjusted in GEOS-Chem such that simulated total gaseous mercury $\left(\mathrm{TGM} \equiv \mathrm{Hg}^{0}+\mathrm{Hg}^{\mathrm{II}}(\mathrm{g})\right)$ concentrations match the global mean observed at land stations.

\section{GEOS-Chem model}

\subsection{General description}

We start from the standard version v9-02 of the GEOS-Chem Hg model (www.geos-chem.org; Amos et al., 2012; Song et al., 2015) and implement a new 2010 inventory for speciated anthropogenic emissions (Zhang et al., 2016) including contributions from commercial products (Horowitz et al., 2014). We then add original updates, described below, for atmospheric chemistry and atmosphere-ocean coupling. The standard v9-02 model includes cycling of $\mathrm{Hg}^{0}$ and $\mathrm{Hg}^{\mathrm{II}}$ between the atmosphere, land, and the surface mixed layer of the ocean (Selin et al., 2008; Soerensen et al., 2010). The atmospheric model transports $\mathrm{Hg}^{0}$ and $\mathrm{Hg}^{\mathrm{II}}$ as separate tracers. Gas-particle partitioning of $\mathrm{Hg}^{\mathrm{II}}$ is parameterized following Amos et al. (2012) as a thermodynamic equilibrium function of local temperature and mass concentration of fine particulate matter $\left(\mathrm{PM}_{2.5}\right)$. This parameterization is based on observed relationships between the gas / particle $\mathrm{Hg}^{\mathrm{II}}$ concentration ratio and $\mathrm{PM}_{2.5}$, and it does not resolve effects from particle composition or surface area.

Holmes et al. (2010) presented the last detailed global atmospheric budget analysis of $\mathrm{Hg}$ in GEOS-Chem, and we use it as a point of comparison for this study. Their model version included $\mathrm{Hg}^{0}$ oxidation by $\mathrm{Br}$ atoms, with $\mathrm{Br}$ concentrations specified in the troposphere and stratosphere from the p-TOMCAT and NASA Global Modeling Initiative models, respectively (Yang et al., 2005; Strahan et al., 2007). The standard v9-02 model uses $\mathrm{Br}$ concentration fields from the GEOS-Chem tropospheric bromine simulation by Parrella et al. (2012) and features other model updates relative to Holmes et al. (2010), including the gas-particle $\mathrm{Hg}^{\mathrm{II}}$ equilibrium partitioning described above, a corrected washout algorithm (Amos et al., 2012), and improvements to the 2-D surface ocean model (Soerensen et al., 2010). In this work we update the $\mathrm{Br}$ concentration fields to a more recent version of
GEOS-Chem (Schmidt et al., 2016), as discussed further in Sect. 3.2.

We conduct a 3-year simulation for 2009-2011 driven by GEOS-5 assimilated meteorological data from the NASA Global Modeling and Assimilation Office (GMAO) with native horizontal resolution of $1 / 2^{\circ} \times 2 / 3^{\circ}$ and 72 vertical levels extending up to the mesosphere. The GEOS-Chem simulation is conducted at $4^{\circ} \times 5^{\circ}$ horizontal resolution by regridding the GEOS-5 meteorological data. We use anthropogenic $\mathrm{Hg}$ emissions for the year 2010 from Zhang et al. (2016). The spatial distribution of soil $\mathrm{Hg}$ is determined following the method of Selin et al. (2008), with updated soil respiration emissions $\left(910 \mathrm{Mg} \mathrm{Hg} \mathrm{yr}^{-1}\right.$ ) for consistency with the mechanistic terrestrial model developed by Smith-Downey et al. (2010). Emissions from snow and re-emission of deposited Hg follow Selin et al. (2008). The model is initialized with a 15-year simulation to equilibrate the stratosphere. We present model results as averages for the three simulation years (2009-2011).

\subsection{Atmospheric chemistry}

$\mathrm{Hg}^{0} / \mathrm{Hg}^{\mathrm{II}}$ redox chemistry in the standard GEOS-Chem v902 model includes $\mathrm{Hg}^{0}$ oxidation by $\mathrm{Br}$ atoms and $\mathrm{Hg}$ II incloud photoreduction as described by Holmes et al. (2010), with $\mathrm{Br}$ concentration fields from Parrella et al. (2012). Shah et al. (2016) updated that chemistry following Dibble et al. (2012) to include second-stage oxidation of $\mathrm{HgBr}$ by $\mathrm{HO}_{2}, \mathrm{NO}_{2}$, and $\mathrm{BrO}$, as well as new kinetics for $\mathrm{HgBr}$ dissociation. Here we further expand and update the chemistry using the mechanism described in Table $1 . \mathrm{Br}$ and $\mathrm{Cl}$ radical concentrations are taken from a new GEOS-Chem simulation of tropospheric oxidant-aerosol chemistry by Schmidt et al. (2016). Unlike Parrella et al. (2012), this simulation does not include a bromine radical source from sea salt debromination as recent evidence suggests that $\mathrm{BrO}$ concentrations in the marine boundary layer (MBL) are generally sub-ppt (Gómez Martín et al., 2013; Wang et al., 2015). Simulated concentrations of $\mathrm{Br}$ in the free troposphere are, on the other hand, a factor of 2 higher than Parrella et al. (2012), reflecting more extensive heterogeneous chemistry. Schmidt et al. (2016) show that their simulation provides a better simulation of aircraft and satellite observations of tropospheric $\mathrm{BrO}$. Stratospheric concentrations of $\mathrm{Br}$ and $\mathrm{Cl}$ species are from the GEOS Chemistry Climate Model (Liang et al., 2010) and Global Modeling Initiative (Considine et al., 2008; Murray et al., 2012), respectively.

We use the global 3-D monthly archive of oxidant and radical concentrations from the GEOS-Chem simulation of Schmidt et al. (2016) that included detailed gas and aerosol chemistry. We apply diurnal scaling following Holmes et al. (2010) to the monthly mean concentrations of $\mathrm{Br}, \mathrm{BrO}$, $\mathrm{Cl}, \mathrm{ClO}$, and $\mathrm{HOCl}$; a cosine function of the solar zenith angle for $\mathrm{OH}$ and $\mathrm{HO}_{2}$; and $\mathrm{NO}-\mathrm{NO}_{2}-\mathrm{O}_{3}$ photochemical equilibrium for $\mathrm{NO}_{2}$. Schmidt et al. (2016) evaluated their 


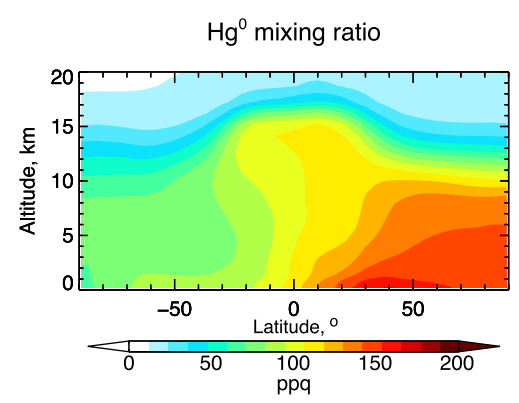

$\mathrm{Hg}^{0}$ oxidation rate: number density

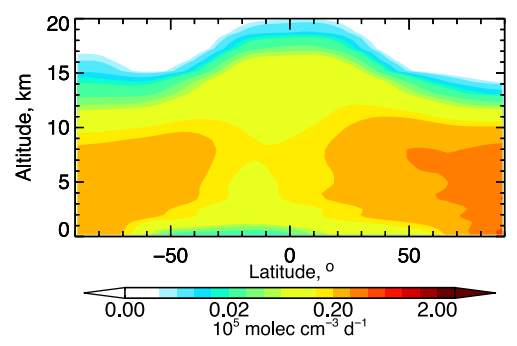

$\mathrm{Hg}^{\prime \prime}$ mixing ratio

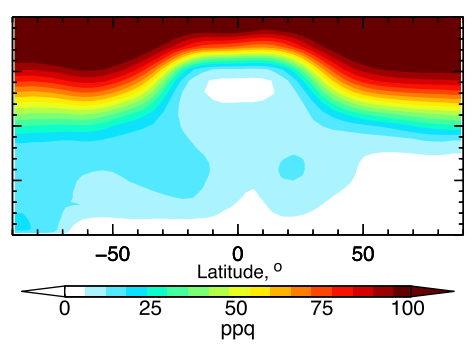

$\mathrm{Hg}^{0}$ oxidation rate: mixing ratio

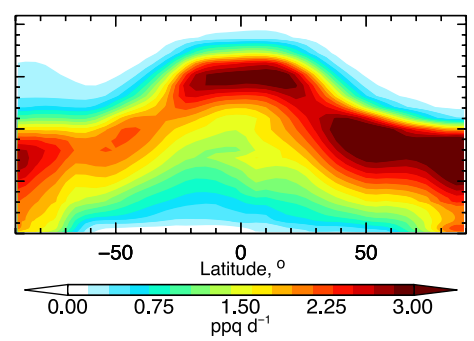

Figure 1. Annual (2009-2011) zonal mean mixing ratios of $\mathrm{Hg}^{0}$ and $\mathrm{Hg}^{\mathrm{II}}$ in GEOS-Chem, and $\mathrm{Hg}^{0}$ oxidation rates in number density and mixing ratio units.

simulated tropospheric $\mathrm{BrO}$ concentrations (global daytime mean of $0.96 \mathrm{ppt}$ ) with observations from satellite and aircraft and found no systematic bias. GEOS-Chem concentrations of $\mathrm{NO}_{2}$ and $\mathrm{H}_{2} \mathrm{O}_{2}$ (proxy for $\mathrm{HO}_{2}$ ) have been evaluated successfully in a number of aircraft campaigns (Martin et al., 2006; Hudman et al., 2007; Singh et al., 2007; Lin and McElroy, 2010; Mao et al., 2010; Travis et al., 2016). GEOS-Chem $\mathrm{NO}_{2}$ columns have also been evaluated against satellite observations over China (Lin et al., 2012), North America (e.g., Lamsal et al., 2014), and Africa (Marais et al., 2012). Fast $\mathrm{Hg}^{0}$ oxidation in the polar spring boundary layer is simulated by specifying high $\mathrm{BrO}$ concentrations when conditions for temperature, sea ice cover, sunlight, and atmospheric stability are met (Holmes et al., 2010). Monthly mean OA concentrations are archived from a separate v9-02 GEOS-Chem simulation including primary emissions from combustion and secondary production from biogenic and anthropogenic hydrocarbons (Pye et al., 2010). An evaluation of modeled OA against aircraft observations globally is presented in Heald et al. (2011), which showed no systematic bias in remote environments but an underestimate of median concentrations in polluted regions. Aqueous-phase concentrations of $\mathrm{Hg}^{0}, \mathrm{O}_{3}$, and $\mathrm{HOCl}$ are determined from the gas-phase partial pressures and Henry's law coefficients (Table 1). We estimate aqueous in-cloud $\mathrm{OH}$ concentrations following Jacob et al. (2005) as $[\mathrm{OH}(\mathrm{aq})]=\beta[\mathrm{OH}(\mathrm{g})]$, with $\beta=1 \times 10^{-19} \mathrm{M} \mathrm{cm}^{3}$ molecule ${ }^{-1}$.

\subsection{Atmosphere-ocean coupling}

GEOS-Chem v9-02 uses a 2-D surface-slab ocean model with no lateral transport and with fixed subsurface ocean concentration boundary conditions (Soerensen et al., 2010). Oceanic circulation and mixing between the surface mixed layer and deeper ocean strongly impact $\mathrm{Hg}^{0}$ concentrations in the surface ocean through the supply of reducible $\mathrm{Hg}^{\mathrm{II}}$, driving changes in oceanic evasion (Soerensen et al., 2013, 2014). Here we present a new two-way coupling of the GEOS-Chem atmospheric Hg simulation to the MITgcm 3D oceanic general circulation model with embedded ecology (Y. X. Zhang et al., 2015). First, the GEOS-Chem Hg model with the 2-D slab ocean is initialized over 15 years of repeated present-day emissions and meteorological data (15 years is required to equilibrate the stratosphere). Starting from these initial conditions, we conduct the GEOS-Chem simulation for the desired period (here 3 years: 2009-2011) and archive monthly surface air $\mathrm{Hg}^{0}$ concentrations and total $\mathrm{Hg}^{\mathrm{II}}$ deposition fluxes. We then initialize the Y. X. Zhang et al. (2015) ocean model for 20 years with these archived surface boundary conditions to equilibrate the upper several hundred meters of the ocean. The monthly mean surface ocean $\mathrm{Hg}^{0}$ concentrations from the final year of the simulation are then input to GEOS-Chem, replacing the 2-D slab ocean model concentrations. The 15-year GEOS-Chem simulation is repeated with this new input. This process is iterated until convergence of results is achieved. We find that two iterations are sufficient. 


\section{Global budget of atmospheric mercury}

\subsection{Budget and lifetimes}

Figure 1 (top panel) shows the simulated vertical and latitudinal distributions of annual zonal mean $\mathrm{Hg}^{0}$ and $\mathrm{Hg}^{\mathrm{II}}$ mixing ratios. The fraction of tropospheric $\mathrm{Hg}^{\mathrm{II}}$ in the aerosol phase ranges from less than 10 to more than $90 \%$ (Amos et al., 2012). Modeled $\mathrm{Hg}^{0}$ decreases rapidly in the stratosphere, while $\mathrm{Hg}^{\mathrm{II}}$ increases with altitude and dominates total $\mathrm{Hg}$ in the stratosphere. This vertical structure is driven by chemistry (Selin et al., 2007; Holmes et al., 2010), and these general vertical trends in the two species are consistent with limited available observations (Murphy et al., 2006; Talbot et al., 2007; Lyman and Jaffe, 2012). The exact partitioning of total $\mathrm{Hg}$ in the stratosphere between $\mathrm{Hg}^{0}$ and $\mathrm{Hg}^{\mathrm{II}}$ is uncertain, and GEOS-Chem predicts a higher $\mathrm{Hg}^{\mathrm{II}}$ fraction relative to other models (Bieser et al., 2016). Photodissociation of gas-phase $\mathrm{Hg}^{\mathrm{II}}$ halides may be possible at ultraviolet wavelengths (Maya, 1977), but whether this is important in the mid-to-upper stratosphere requires further investigation. The stratosphere in the model accounts for $12 \%$ of total $\mathrm{Hg}$ atmospheric mass and is in a very different redox regime from the troposphere. Here we focus on tropospheric budgets, which are most relevant to $\mathrm{Hg}$ deposition. The stratosphere is discussed further in Sect. 4.4.

Figure 2 shows the global tropospheric $\mathrm{Hg}$ budget from our GEOS-Chem simulation, including the rates of the major $\mathrm{Hg}^{0} / \mathrm{Hg}^{\mathrm{II}}$ cycling pathways. The global tropospheric $\mathrm{Hg}$ reservoir is $3900 \mathrm{Mg}$, including $3500 \mathrm{Mg}$ as $\mathrm{Hg}^{0}$ and $400 \mathrm{Mg}$ as $\mathrm{Hg}^{\mathrm{II}}$, smaller than the $4500 \mathrm{Mg}$ reservoir in Holmes et al. (2010). In both cases, the reservoir was adjusted through the $\mathrm{Hg}^{\mathrm{II}}$ photoreduction rate coefficient to match the observed annual mean TGM at long-term monitoring sites, mainly located at northern midlatitudes (Fig. 3). Holmes et al. (2010) used observations for 2000-2008 averaging $1.87 \pm 1.00 \mathrm{ng} \mathrm{m}^{-3} \mathrm{STP}$ ( $p=1 \mathrm{~atm}, T=273 \mathrm{~K} ; n=$ 39 sites), whereas we use observations for 2007-2013 averaging $1.46 \pm 0.25 \mathrm{ng} \mathrm{m}^{-3} \mathrm{STP}(n=37)$. Observed atmospheric concentrations in North America and Europe have declined on average by $1-2 \% \mathrm{yr}^{-1}$ since 1990 , which has been attributed to the phase-out of $\mathrm{Hg}$ from commercial products and declines in coal $\mathrm{Hg}$ emissions as a co-benefit of $\mathrm{SO}_{2}$ and $\mathrm{NO}_{x}$ emission controls (Zhang et al., 2016). Observations used in Holmes et al. (2010) also included very high concentrations at four East Asian sites (3-7 $\mathrm{ng} \mathrm{m}^{-3} \mathrm{STP}$; Nguyen et al., 2007; Sakata and Asakura, 2007; Feng et al., 2008; Wan et al., 2009), whereas the more recent observations over East Asia used here $(n=6)$ are all less than $3 \mathrm{ng} \mathrm{m}^{-3}$ STP (Sheu et al., 2010; Fu et al., 2012a, b; H. Zhang et al., 2015). Only one site (Mt. Changbai, China) has data available during both time periods, and observed TGM concentrations decreased there by a factor of 2 (Fu et al., 2012b). Thus, our atmospheric loadings may be more representative of recent (ca. 2010) conditions.

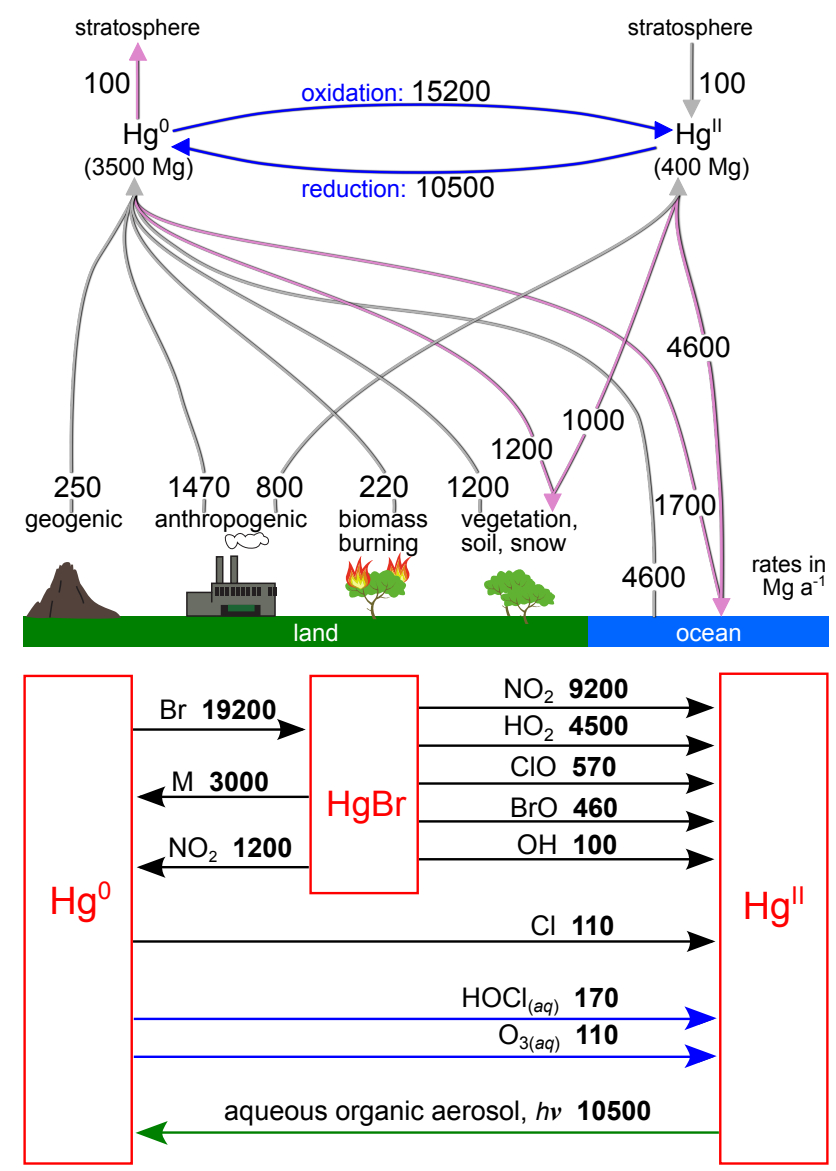

Figure 2. Global budget of tropospheric mercury in GEOS-Chem. $\mathrm{Hg}^{\mathrm{II}}$ includes gaseous and particulate forms in local thermodynamic equilibrium (Amos et al., 2012). The bottom panel identifies the major chemical reactions from Table 1 cycling $\mathrm{Hg}^{0}$ and $\mathrm{Hg}^{\mathrm{II}}$. Reactions with global rates lower than $100 \mathrm{Mg} \mathrm{yr}^{-1}$ are not shown.

We calculate several atmospheric lifetimes to understand the processes driving $\mathrm{Hg}$ deposition: the chemical lifetime of $\mathrm{Hg}^{0}$ against oxidation, the chemical lifetime of $\mathrm{Hg}^{\mathrm{II}}$ against reduction, the lifetime of $\mathrm{Hg}^{\mathrm{II}}$ against deposition, and the lifetime of total gaseous mercury $\left(\mathrm{TGM} \equiv \mathrm{Hg}^{0}+\mathrm{Hg}^{\mathrm{II}}(\mathrm{g})\right.$ ) against deposition. We find that the lifetime of $\mathrm{Hg}^{0}$ against oxidation to $\mathrm{Hg}^{\mathrm{II}}$ in the troposphere is 2.7 months, with $\mathrm{Br}$ atom-initiated pathways contributing $97 \%$ of total oxidation. This chemical lifetime is smaller than most prior model estimates, e.g., 6 months in Holmes et al. (2010), which used lower $\mathrm{Br}$ concentrations. The addition of $\mathrm{NO}_{2}$ and $\mathrm{HO}_{2}$ as second-stage oxidants is also important in increasing the rate of $\mathrm{HgBr}$ conversion to $\mathrm{Hg}^{\mathrm{II}}$, more than compensating for faster thermal decomposition of $\mathrm{HgBr}$ relative to Holmes et al. (2010). Our results are consistent with Shah et al. (2016), who estimated a global annual tropospheric $\mathrm{Hg}^{0}$ lifetime against oxidation to $\mathrm{Hg}^{\mathrm{II}}$ by $\mathrm{Br}$ atoms of 1.2 to 2.8 months, based on their simulation of measurements of $\mathrm{Hg}^{\mathrm{II}}$ over the southeastern US in summer during the Nitrogen, Oxidants, 
Mercury and Aerosol Distributions, Sources and Sinks (NOMADSS) campaign (Gratz et al., 2015). The dominance of $\mathrm{NO}_{2}$ and $\mathrm{HO}_{2}$ as $\mathrm{HgBr}$ oxidants reflects their high atmospheric abundance and is consistent with results from a box modeling study over the Pacific (Wang et al., 2014). We find $\mathrm{Cl}$ atoms contribute less than $1 \%$ of $\mathrm{Hg}^{0}$ oxidation globally because the supply of $\mathrm{Cl}$ atoms (mean tropospheric mixing ratio of $2 \times 10^{-4} \mathrm{ppt}$ ) is limited by fast conversion to the stable reservoir $\mathrm{HCl}$. Aqueous-phase pathways in clouds contribute $2 \%$. Our work suggests that the dominant $\mathrm{Hg}^{\mathrm{II}}$ species produced in the gas phase are $\mathrm{BrHgONO}$ and $\mathrm{BrH}-$ $\mathrm{gOOH}$, though the actual speciation of $\mathrm{Hg}^{\mathrm{II}}$ in the atmosphere would likely be modified through cycling in aerosols and clouds (Hedgecock and Pirrone, 2001; Lin et al., 2006). We did not consider heterogeneous $\mathrm{Hg}^{0}$ oxidation on particle surfaces (e.g., Vidic et al., 1998; Flora et al., 1998; Lee et al., 2004) due to inadequate information to formulate atmospheric rates. Further study of heterogeneous $\mathrm{Hg}^{0}$ oxidation is needed (Ariya et al., 2015).

The vertical distribution of $\mathrm{Hg}^{0} \rightarrow \mathrm{Hg}^{\mathrm{II}}$ oxidation rates is shown in the bottom panel of Fig. 1 in units of number density (relevant to the mass budget) and mixing ratio (relevant to transport). Only $1 \%$ of $\mathrm{Hg}^{0}$ oxidation occurs in the stratosphere, consistent with previous work (Holmes et al., 2010). Most $\mathrm{Hg}$ oxidation by mass occurs in the extratropical free troposphere, consistent with the $\mathrm{Br}$ distribution (Schmidt et al., 2016), and is faster in the Northern Hemisphere because of higher $\mathrm{NO}_{2}$ concentrations. $\mathrm{Hg}^{0}$ oxidation in Holmes et al. (2010) was fastest in the Southern Ocean MBL due to high $\mathrm{Br}$ concentrations from sea salt aerosol debromination, but debromination in that region is unlikely since the sea salt aerosol remains alkaline (Murphy et al., 1998; Alexander et al., 2005; Schmidt et al., 2016). In general, the addition of second-stage oxidants $\mathrm{HO}_{2}$ and $\mathrm{NO}_{2}$ shifts $\mathrm{Hg}$ oxidation to lower latitudes relative to Holmes et al. (2010). This has implications for $\mathrm{Hg}$ deposition, which we discuss in Sect. $5 . \mathrm{Hg}^{0}$ oxidation in terms of mixing ratio features a secondary maximum in the tropical upper troposphere, where the $\mathrm{Br} / \mathrm{BrO}$ ratio is high (Parrella et al., 2012; Fernandez et al., 2014).

We find that the shorter chemical lifetime of $\mathrm{Hg}^{0}$ in our simulation relative to Holmes et al. (2010) must be balanced by faster atmospheric reduction to reproduce observed TGM concentrations. This is implemented by adjusting the photoreduction coefficient $\alpha$ in Table 1 . The resulting mean lifetime of $\mathrm{Hg}^{\mathrm{II}}$ against reduction in the troposphere is 13 days. Shah et al. (2016) similarly found that faster $\mathrm{Hg}^{0}$ oxidation as needed to match NOMADSS observations required faster $\mathrm{Hg}^{\mathrm{II}}$ reduction, with a tropospheric $\mathrm{Hg}^{\mathrm{II}}$ lifetime against reduction of 19 days. The lifetime of tropospheric $\mathrm{Hg}^{\mathrm{II}}$ against deposition is relatively long, 26 days (see Fig. 2), because most $\mathrm{Hg}^{\mathrm{II}}$ production occurs in the free troposphere, where precipitation is infrequent (Fig. 1). $\mathrm{Hg}^{\mathrm{II}}$ reduction in the model is faster in the Northern Hemisphere than in the Southern Hemisphere because of higher OA concentrations. Hence

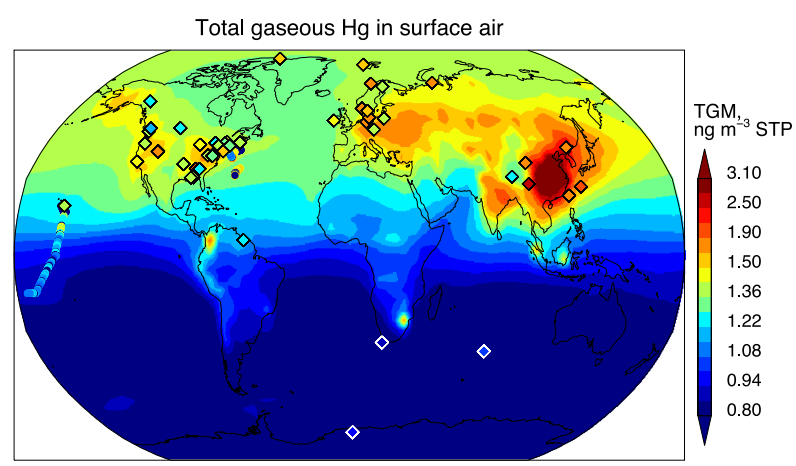

Figure 3. Global distribution of total gaseous mercury (TGM) concentrations in surface air in units of $\mathrm{ng} \mathrm{m}^{-3} \mathrm{STP}$ ( $p=1 \mathrm{~atm}, T=$ $273 \mathrm{~K}$ ). Model values (background) are annual means for 2009 2011. Observations (symbols) are for 2007-2013. Data for land sites (diamonds) are annual means for 2007-2013 as previously compiled by Song et al. (2015) and Zhang et al. (2016). Observations from 2007-2013 ship cruises (circles) are from Soerensen et al. $(2013,2014)$. Note the change in the linear color scale at $1.50 \mathrm{ng} \mathrm{m}^{-3}$.

$\mathrm{Hg}^{\mathrm{II}}$ concentrations are higher in the Southern Hemisphere than in the Northern Hemisphere (Fig. 1).

We find here that the $\mathrm{Hg}^{\mathrm{II}}$ lifetime against reduction is shorter than against deposition, emphasizing the importance of reduction in controlling the atmospheric $\mathrm{Hg}$ budget. By contrast, Holmes et al. (2010) found an $\mathrm{Hg}^{\mathrm{II}}$ tropospheric lifetime of 50 days against reduction and 36 days against deposition, which led them to conclude that no reduction would be needed if $\mathrm{Hg}^{0}$ oxidation kinetics were decreased within their uncertainty. This is no longer possible in our simulation because of the much faster $\mathrm{Hg}^{0}$ oxidation. We conclude that atmospheric $\mathrm{Hg}^{\mathrm{II}}$ reduction must take place, although the mechanism is not established. With $\mathrm{Hg}^{\mathrm{II}}$ reduction, the overall lifetime of tropospheric TGM against deposition in our simulation is 5.2 months, similar to the estimate of 6.1 months in Holmes et al. (2010). We discuss the consistency of this estimate with observations in the next section.

\subsection{Global distribution}

Figure 3 compares our simulation to observed 2007-2013 TGM surface concentrations. TGM includes $\mathrm{Hg}^{0}$ and the gaseous component of $\mathrm{Hg}^{\mathrm{II}}$. Observations include annual means at 37 land sites plus ship cruises. The spatial correlation coefficient between model and observations is $r=0.57$. The mean at land stations is $1.47 \pm 0.27 \mathrm{ng} \mathrm{m}^{-3}$ STP in the observations and $1.44 \pm 0.25 \mathrm{ng} \mathrm{m}^{-3} \mathrm{STP}$ in the model, with the good agreement in the mean reflecting the adjustment of the $\mathrm{Hg}^{\mathrm{II}}$ photoreduction rate coefficient as explained above.

Beyond this simulation of the mean, we successfully reproduce the observed standard deviation of TGM concentrations, which places an independent constraint on the atmospheric lifetime of $\mathrm{Hg}$ against deposition (Junge, 1974; 
Hamrud, 1983). This constraint had previously been expressed in terms of the interhemispheric gradient of TGM from ship cruises, leading to TGM lifetime estimates ranging from 4.4 months to 2 years (Slemr et al., 1981; Fitzgerald et al., 1983; Lindqvist and Rodhe, 1985; Lamborg et al., 2002). However, we find the interhemispheric gradient in surface concentrations is not a sensitive diagnostic of lifetime because surface atmospheric $\mathrm{Hg}$ in the Southern Hemisphere is controlled more by atmosphere-ocean exchange than by transport from the Northern Hemisphere. For example, changing the simulation of atmosphere-ocean exchange from the slab ocean to the MITgcm (Sect. 3.3) increases the TGM lifetime while also increasing the interhemispheric gradient due to changed ocean emissions. We conducted a sensitivity simulation doubling the tropospheric TGM lifetime in the model (to 10.4 months) by decreasing the rate of $\mathrm{Hg}^{0}$ oxidation. This produced less than $20 \%$ of a decline in the interhemispheric gradient, but the relative standard deviation of TGM concentrations across land stations decreased by $40 \%$. Thus the overall variability of TGM concentrations provides a more sensitive constraint on the TGM atmospheric lifetime, while the interhemispheric gradient can be misleading. The model's ability to reproduce the observed standard deviation across land sites supports our simulated TGM atmospheric lifetime of 5.2 months.

\subsection{Seasonality}

Figure 4 compares simulated and observed seasonal cycles of TGM concentrations at land stations at northern midlatitudes ( 30 to $60^{\circ} \mathrm{N}$ ) and in the Southern Hemisphere (see Fig. 3 for site locations). Also shown are results from a sensitivity simulation with the 2-D surface-slab ocean model (Soerensen et al., 2010). The observed seasonal cycle is successfully reproduced in the Northern Hemisphere. The February maximum and September minimum are driven in the model in part by $\mathrm{Hg}^{0}$ oxidation and in part by ocean evasion. Seasonality in radical oxidant concentrations outweighs temperature effects, leading to fastest oxidation in summer and slowest in winter. Modeled oceanic $\mathrm{Hg}^{0}$ evasion from the North Atlantic Ocean peaks in winter and early spring, because higher wind speeds increase mixing and entrainment of reducible $\mathrm{Hg}^{\mathrm{II}}$ from subsurface waters and enhance the rate of air-sea exchange, and $\mathrm{Hg}$ removal via particle settling during this time is low (Sorensen et al., 2010, 2013). Similar to Song et al. (2015), we find that the 2-D slab ocean overestimates the observed seasonality at northern midlatitude sites (Fig. 4). Atlantic and Pacific Ocean seawater $\mathrm{Hg}^{0}$ measurements indicate this overestimate results from oversimplified ocean physics and the fixed boundary condition for subsurface ocean concentrations in the slab ocean model (Soerensen et al., 2014). Previous work shows one-way coupling to the MITgcm ocean simulation improves simulated surface ocean $\mathrm{Hg}^{0}$ concentrations compared to observations

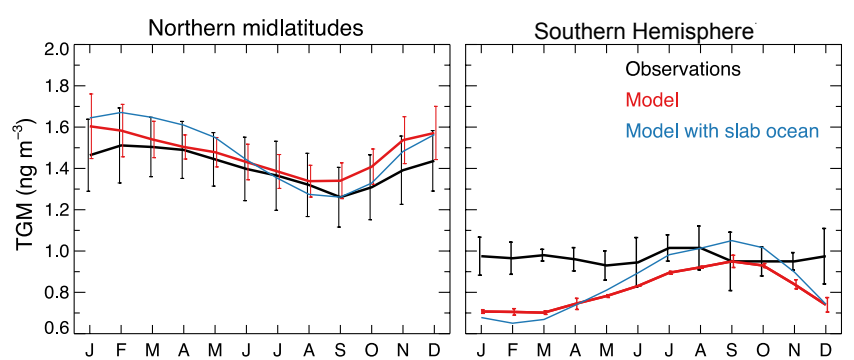

Figure 4. Mean seasonal variation and spatial standard deviation of total gaseous mercury (TGM) concentrations for northern midlatitude sites (see Fig. 3) and Southern Hemisphere sites (Amsterdam Island and Cape Point). Observations are compared to our standard GEOS-Chem simulation coupled to the MITgcm 3-D ocean model and to a sensitivity simulation coupled to the 2-D surfaceslab ocean model in GEOS-Chem.

(Soerensen et al., 2014). Here, the two-way coupling to the $\mathrm{MITgcm}$ also improves the seasonality in atmospheric $\mathrm{Hg}$.

In the Southern Hemisphere, Amsterdam Island in the Indian Ocean and Cape Point on the South African coast have similar monthly average concentrations and show no significant seasonal variation (Angot et al., 2014; Slemr et al., 2015). By contrast, the model at those sites has strong seasonality, as previously shown for the standard model version v9-02 (Song et al., 2015). We find a modest improvement in moving from the slab ocean simulation to the MITgcm, but the seasonal bias is still large. Long-range transport of atmospheric $\mathrm{Hg}$ from Antarctica could influence observed seasonality at these sites (Angot et al., 2016). Capturing the seasonality of atmospheric $\mathrm{Hg}$ in the Arctic using GEOSChem required parameterization of unique sea ice, oceanic, and riverine dynamics (Fisher et al., 2012, 2013; Y. Zhang et al., 2015); a similar analysis for the Southern Ocean region, with its distinct productivity dynamics impacting $\mathrm{Hg}$ cycling (e.g., Cossa et al., 2011; Gionfriddo et al., 2016), has not yet been performed.

\subsection{Vertical distribution and the stratosphere}

$\mathrm{Hg}^{0}$ concentrations in the model drop rapidly above the tropopause (Fig. 1), consistent with observations (Talbot et al., 2007; Slemr et al., 2009). Modeled $\mathrm{Hg}^{0}$ oxidation in the lower stratosphere is almost exclusively from $\mathrm{Br}$ atoms. There is no significant $\mathrm{Hg}^{\mathrm{II}}$ reduction there because OA concentrations and relative humidity are very low. Extensive TGM observations in the lowermost stratosphere at northern extratropical latitudes are available from the Civil Aircraft for the Regular Investigation of the atmosphere Based on an Instrument Container (CARIBIC) program, which collects measurements aboard commercial aircraft (Slemr et al., $2009,2014,2016)$. The early stratospheric data were biased low, and we focus on corrected data available for April 2014January 2015 (Slemr et al., 2016). TGM in the stratosphere is 


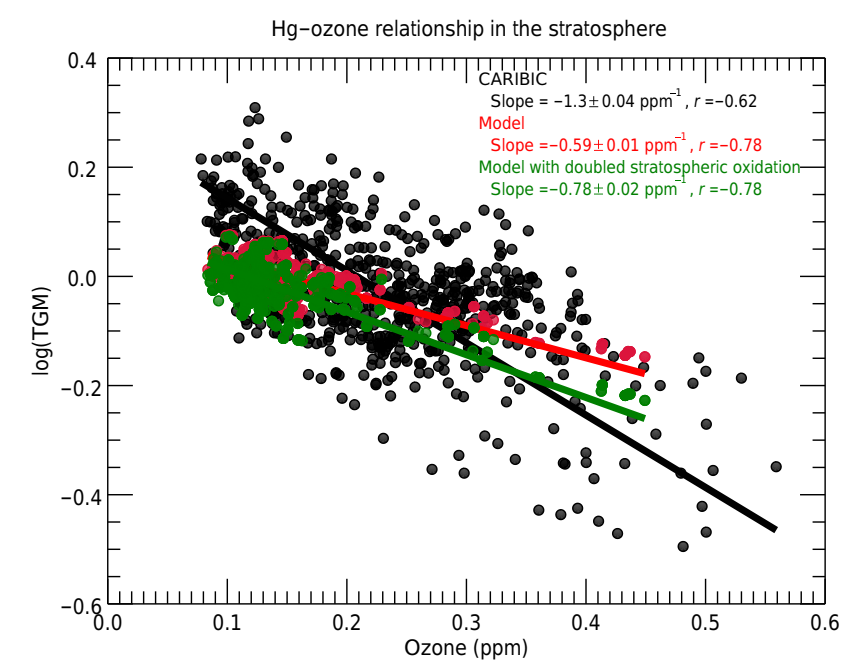

Figure 5. Relationship between total gaseous mercury (TGM) and ozone concentrations in the lower stratosphere. TGM is shown as the decimal logarithm of the concentration in units of $n g \mathrm{~m}^{-3}$ STP. Observations are from CARIBIC commercial aircraft in the extratropical Northern Hemisphere for April 2014January 2015 (Slemr et al., 2015). Tropospheric data as diagnosed by $\left[\mathrm{O}_{3}\right] /[\mathrm{CO}]<1.25 \mathrm{~mol} \mathrm{~mol}^{-1}$ are excluded. Model points are data for individual flights sampled along the CARIBIC flight tracks on the GEOS-Chem $4^{\circ} \times 5^{\circ}$ model grid. Also shown are results from a model sensitivity simulation with a doubled $\mathrm{Hg}^{0}$ oxidation rate in the stratosphere. Reduced-major-axis (RMA) regressions for the $\log$ (TGM)-ozone relationship are shown with slopes and correlation coefficients $(r)$. Errors on the slopes are estimated by the bootstrap method.

expected to be mainly $\mathrm{Hg}^{0}$ because $\mathrm{Hg}^{\mathrm{II}}$ is incorporated into aerosol (Murphy et al., 2006; Lyman and Jaffe, 2012).

Figure 5 compares the stratospheric TGM concentrations measured in CARIBIC to model values sampled along the flight tracks. The CARIBIC data also include ozone $\left(\mathrm{O}_{3}\right)$ and CO concentrations (Brenninkmeijer et al., 2007). Here we use $\mathrm{O}_{3}$ concentration as a chemical coordinate for depth into the stratosphere and exclude tropospheric data as diagnosed by $\left[\mathrm{O}_{3}\right] /[\mathrm{CO}]<1.25 \mathrm{~mol} \mathrm{~mol}^{-1}$ (Hudman et al., 2007). We correlate the logarithm of TGM concentrations, as a measure of first-order loss, to the $\mathrm{O}_{3}$ concentrations. The observations reach higher ozone than the model, indicating that they sample air with greater stratospheric influence. The model underestimates the $\log$ (TGM)-ozone slope by a factor of 2 . To test whether this underestimate is due to slow $\mathrm{Hg}^{0}$ oxidation, we performed a sensitivity simulation doubling the stratospheric $\mathrm{Hg}^{0}$ oxidation rate (green line in Fig. 5). The model slope increased by only $32 \%$. This suggests that the $\log$ (TGM)-ozone relationship in the lowermost stratosphere is set in part by mixing rather than solely by chemistry (Xiao et al., 2007). The model underestimate of the $\log$ (TGM)-ozone slope could reflect excessive dynamical mixing in the lower stratosphere, a well-known problem in stratospheric transport models (Schoeberl et al., 2003; Tan et al., 2004), or errors in the timescales of air transit across the tropopause, which vary on the order of months to years (Orbe et al., 2014; Ploeger and Birner, 2016).

\section{Implications for global $\mathrm{Hg}$ deposition}

Figure 6 compares simulated and observed annual $\mathrm{Hg}$ wet deposition at sites in North America, Europe, and China for 2007-2013. The model captures the spatial variability across sites in North America relatively well $(r=0.57)$. Some of this variability is driven by precipitation amount, which leads to higher modeled deposition along the northwest coast and over the North Atlantic. The maximum along the coast of the Gulf of Mexico is due to deep convection scavenging uppertropospheric air enriched in $\mathrm{Hg}^{\mathrm{II}}$ (Guentzel et al., 2001; Selin and Jacob, 2008; Holmes et al., 2016). Previous GEOSChem simulations with $\mathrm{Br}$-initiated oxidation of $\mathrm{Hg}^{0}$ failed to capture this maximum because $\mathrm{Hg}^{\mathrm{II}}$ production favored higher latitudes (Holmes et al., 2010; Amos et al., 2012). The inclusion of $\mathrm{NO}_{2}$ and $\mathrm{HO}_{2}$ as second-stage oxidants in our simulation shifts $\mathrm{Hg}^{\mathrm{II}}$ production to lower latitudes and matches the general location of the Gulf of Mexico maximum, although the magnitude is still underestimated. Increasing horizontal resolution in the model could improve the definition of the maximum (Zhang et al., 2012).

Over Europe, deposition is fairly uniform and low in the model and observations. This reflects decreased anthropogenic $\mathrm{Hg}^{\mathrm{II}}$ emissions in the region from emissions controls on coal-fired power plants (Klimont et al., 2013; Muntean et al., 2014; Zhang et al., 2016). There is no area of frequent deep convection, unlike the Gulf of Mexico for the US.

Observations of $\mathrm{Hg}$ wet deposition over China have recently become available (Fu et al., 2015, 2016). Values at urban sites are high, likely reflecting local $\mathrm{Hg}^{\mathrm{II}}$ emissions, and are correlated with high concentrations of particulate $\mathrm{Hg}^{\text {II }}$ (Fu et al., 2016). Values at rural sites are much lower and comparable to wet deposition observed in North America and Europe despite higher TGM concentrations in China (see Fig. 3). We simulate these low values successfully in our model, whereas a simulation with the standard GEOS-Chem v9-02 overestimates them by a factor of 4 . This reflects in part our dependence of $\mathrm{Hg}^{\mathrm{II}}$ reduction on OA concentrations, which are particularly high in China (Heald et al., 2011). Decreasing wet deposition in this region in the model has implications for the long-range transport of atmospheric $\mathrm{Hg}$ from East Asia (Weiss-Penzias et al., 2007).

Figure 7 shows the global distribution of wet and dry $\mathrm{Hg}^{\mathrm{II}}$ deposition in the model. This deposition is the main $\mathrm{Hg}$ source to the open ocean (Sunderland and Mason, 2007; Soerensen et al., 2010). We find that $80 \%$ of global $\mathrm{Hg}^{\mathrm{II}}$ deposition is to the oceans, compared to $71 \%$ in Holmes et al. (2010), and that $60 \%$ of this deposition is wet. Even though surface $\mathrm{Hg}^{0}$ concentrations are higher over land, most 


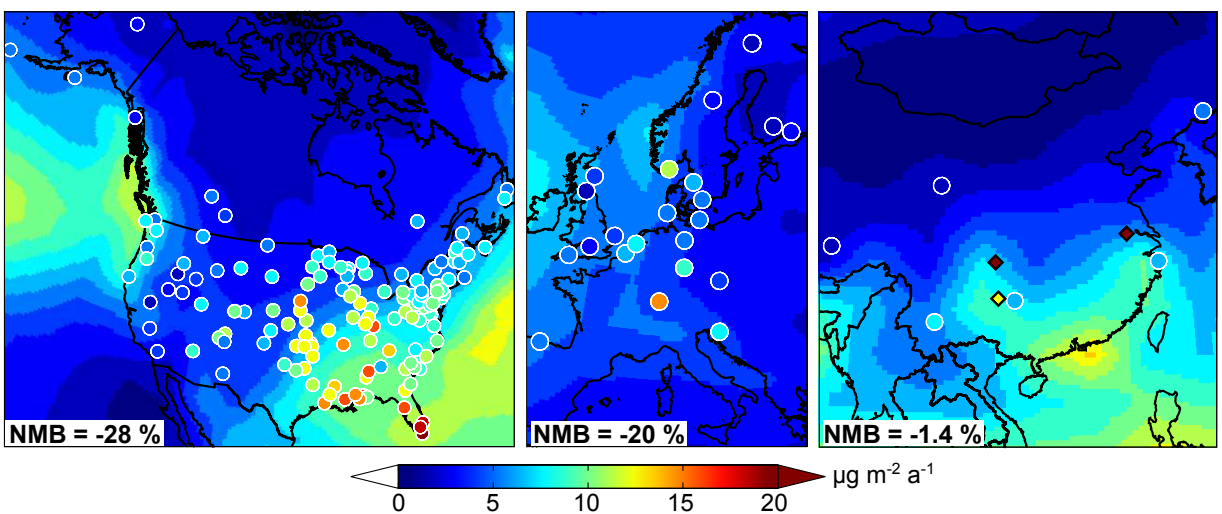

Figure 6. Annual Hg wet deposition fluxes over North America, Europe, and China. Model values for 2009-2011 (background contours) are compared to 2007-2013 observations from the Mercury Deposition Network (MDN, National Atmospheric Deposition Program, http://nadp. sws.uiuc.edu/mdn/) over North America (58 sites), the European Monitoring and Evaluation Programme (EMEP) over Europe (20 sites), and data from Fu et al. (2015, 2016) over China (9 sites). In the China panel, circles represent rural sites, and diamonds represent urban sites as identified in Fu et al. (2015, 2016). For the MDN and EMEP networks, which collect weekly or monthly integrated samples, we only include sites with at least $75 \%$ of annual data for at least 1 year between 2007 and 2013; for China we only include sites with at least 9 months of data over the 2007-2013 period. MDN data are formally quality-controlled, while for EMEP data we rely on a subset of sites that have been quality-controlled (O. Travnikov, personal communication, 2016). Legends give the normalized mean bias (NMB) for all sites, excluding urban sites in China.

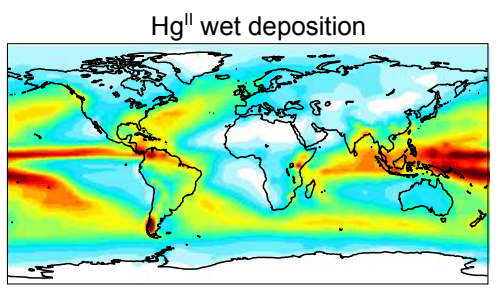

$\mathrm{Hg}^{\prime \prime}$ dry deposition

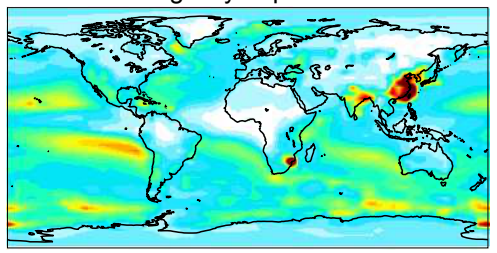

$\mathrm{Hg}^{\prime \prime}$ total deposition

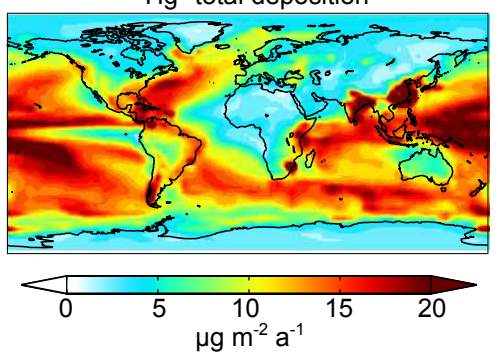

Figure 7. Annual $2009-2011 \mathrm{Hg}^{\mathrm{II}}$ deposition fluxes in GEOSChem.

$\mathrm{Hg}^{0}$ oxidation takes place in the free troposphere and is globally distributed (Fig. 1). Concentrations of $\mathrm{Br}$ atoms are higher over oceans, reflecting their marine origin (Schmidt et al., 2016). The dependence of $\mathrm{Hg}^{\mathrm{II}}$ reduction in our mech- anism on the formation of $\mathrm{Hg}$-organic complexes further shifts $\mathrm{Hg}^{\mathrm{II}}$ deposition away from continents where OA concentrations are highest (Heald et al., 2011). The change in $\mathrm{Br}$ distribution and dominance of $\mathrm{HO}_{2}$ and $\mathrm{NO}_{2}$ as second-stage oxidants for $\mathrm{HgBr}$ shifts $\mathrm{Hg}^{\mathrm{II}}$ deposition to lower latitudes relative to the simulation by Holmes et al. (2010), where most deposition occurred over high-latitude oceans. We now find $49 \%$ of global total $\mathrm{Hg}^{\mathrm{II}}$ deposition is to tropical oceans $\left(30^{\circ} \mathrm{S}-30^{\circ} \mathrm{N}\right)$. The global ocean is a net sink for total atmospheric $\mathrm{Hg}$ of $1700 \mathrm{Mg} \mathrm{yr}^{-1}$ (Fig. 2), with approximately half taken up by tropical oceans. A large $\mathrm{Hg}^{\mathrm{II}}$ deposition flux to the tropical oceans is suggested by recent cruise observations of high oceanic $\mathrm{Hg}^{0}$ concentrations across the Intertropical Convergence Zone (ITCZ), which GEOS-Chem previously underestimated (Soerensen et al., 2014).

\section{Conclusions}

The atmospheric redox chemistry of mercury $\left(\mathrm{Hg}^{0} / \mathrm{Hg}^{\mathrm{II}}\right)$ determines the global patterns of $\mathrm{Hg}$ deposition to surface ecosystems. Here we developed an updated chemical mechanism for use in atmospheric models and evaluated it in the GEOS-Chem global model to gain new insights into the global $\mathrm{Hg}$ budget and the patterns of $\mathrm{Hg}$ deposition. As part of this work we also developed a new coupling between GEOS-Chem and a 3-D ocean general circulation model (MITgcm), resulting in a fully resolved simulation of $\mathrm{Hg}$ transport and chemistry in the atmosphere-ocean system.

The updated atmospheric $\mathrm{Hg}^{0} / \mathrm{Hg}^{\mathrm{II}}$ redox mechanism includes gas-phase $\mathrm{Br}$ as the main $\mathrm{Hg}^{0}$ oxidant in the troposphere and stratosphere, and second-stage oxidation of $\mathrm{HgBr}$ 
by a number of radical oxidants including $\mathrm{NO}_{2}$ and $\mathrm{HO}_{2}$. $\mathrm{Br}$ concentrations in GEOS-Chem are from the recent simulation of Schmidt et al. (2016), and they are higher than previous models and more consistent with recent aircraft and satellite observations of $\mathrm{BrO}$. Atmospheric reduction of $\mathrm{Hg}^{\mathrm{II}}$ is hypothesized to take place by photolysis of aqueous-phase $\mathrm{Hg}^{\mathrm{II}}$-organic complexes. This is parameterized in GEOSChem as a function of the local concentration of organic aerosol.

The global mass of atmospheric $\mathrm{Hg}$ simulated by GEOSChem is $4400 \mathrm{Mg}$, including $3900 \mathrm{Mg}$ in the troposphere. The tropospheric lifetime of $\mathrm{Hg}^{0}$ against oxidation is 2.7 months. Observations of the atmospheric variability of total gaseous mercury $\left(\mathrm{TGM} \equiv \mathrm{Hg}^{0}+\mathrm{Hg}^{\mathrm{II}}(\mathrm{g})\right.$ ) suggest an atmospheric lifetime against deposition of about 6 months. Thus, $\mathrm{Hg}^{\mathrm{II}}$ must be reduced in the atmosphere, which is consistent with recent observations of atmospheric $\mathrm{Hg}$ isotope fractionation. Matching the observed mean surface TGM concentrations in GEOS-Chem implies a tropospheric $\mathrm{Hg}^{\mathrm{II}}$ lifetime of 13 days against reduction and 26 days against deposition. This results in an overall tropospheric lifetime for TGM of 5.2 months against deposition and enables a successful simulation of the observed relative standard deviation of TGM concentrations across terrestrial sites. The interhemispheric difference in TGM concentrations had previously been interpreted to suggest a longer TGM lifetime against deposition, but we show this is misleading because TGM in the Southern Hemisphere is mostly controlled by oceanic emissions rather than transport from the Northern Hemisphere.

The observed seasonality of TGM concentrations at northern midlatitudes (maximum in February, minimum in September) is reproduced by the model, where it is attributed to photochemical oxidation of $\mathrm{Hg}^{0}$ and oceanic evasion, both with similar seasonal effects on TGM concentrations. Coupling GEOS-Chem to the MITgcm 3-D ocean model improves simulation of the seasonal amplitude by lowering oceanic evasion over the North Atlantic due to elimination of the static subsurface ocean boundary condition in the GEOSChem slab ocean and more realistic ocean physics. Observations at Southern Hemisphere sites show little seasonality, whereas the model features a spring maximum. More work is needed to understand this discrepancy.

Observations show a rapid depletion of TGM above the tropopause, and we examined whether this could provide a test for $\mathrm{Hg}^{0}$ chemistry. For that purpose we used extensive lowermost-stratospheric observations from the CARIBIC program aboard commercial aircraft and characterized TGM first-order loss as the slope of the $\log (\mathrm{TGM})$-ozone relationship. We find that the model underestimates the observed $\log$ (TGM)-ozone slope by a factor of 2 but that this slope is only moderately sensitive to the rate of $\mathrm{Hg}^{0}$ oxidation and appears to be driven in part by mixing of air parcels with different stratospheric ages. This mixing is likely too fast in
GEOS-Chem, which may explain the weaker TGM-ozone slope.

Hg wet deposition fluxes in the model are consistent with spatial patterns observed in North America and Europe. Inclusion of $\mathrm{NO}_{2}$ and $\mathrm{HO}_{2}$ as second-stage $\mathrm{HgBr}$ oxidants in the model shifts $\mathrm{Hg}^{\mathrm{II}}$ production to lower latitudes as compared to previous versions of GEOS-Chem and enables the model to capture the location of the observed maximum in wet deposition along the Gulf Coast of the US. However, the magnitude of this Gulf Coast maximum is still underestimated. In rural areas of China, wet deposition is observed to be low despite very high TGM concentrations. This is reproduced by the model, where it is due to fast $\mathrm{Hg}^{\mathrm{II}}$ reduction, driven in part by very high OA concentrations.

We find that $80 \%$ of global $\mathrm{Hg}^{\mathrm{II}}$ deposition takes place over the oceans, reflecting in part the marine origin of $\mathrm{Br}$ as well as the relatively low marine OA concentrations and hence slow $\mathrm{Hg}^{\text {II }}$ reduction. More $\mathrm{Hg}$ is deposited to the tropical oceans (49\% of total $\mathrm{Hg}^{\mathrm{II}}$ deposition) than in previous versions of GEOS-Chem, where debromination of sea salt aerosol drove fast $\mathrm{Hg}^{0}$ oxidation and deposition to the Southern Ocean. Observations of the latitudinal gradient of $\mathrm{Hg}^{\mathrm{II}}$ wet deposition over the ocean would provide a sensitive test of $\mathrm{Hg}$ chemistry and improve understanding of $\mathrm{Hg}$ inputs to different ocean regions.

Code and data availability. Model code used in this study will be made publicly available at http://www.geos-chem.org in an upcoming version through the standard GEOS-Chem procedures. Observational data and code to create model-observation comparison figures are available for download at https://github.com/GC-Hg/ $\mathrm{HgBenchmark/.} \mathrm{Aircraft} \mathrm{data} \mathrm{from} \mathrm{CARIBIC} \mathrm{are} \mathrm{available} \mathrm{through}$ the Global Mercury Observing System (GMOS) at http://sdi.iia.cnr. it/geoint/publicpage/GMOS/gmos_aircraft.zul.

Competing interests. The authors declare that they have no conflict of interest.

Acknowledgements. This work was funded by the Atmospheric Chemistry, Chemical Oceanography, and Environmental Chemical Sciences programs of the US National Science Foundation. We thank Oleg Travnikov for providing quality-controlled EMEP wet deposition measurements and the CARIBIC team (www.caribic-atmospheric.com) for maintaining this valuable measurement program. We thank Jeroen Sonke for helpful discussions. We thank the editor, Ian Hedgecock, and three anonymous reviewers for their thoughtful suggestions.

Edited by: R. Ebinghaus

Reviewed by: I. M. Hedgecock and three anonymous referees 


\section{References}

Alexander, B., Park, R. J., Jacob, D. J., Li, Q. B., Yantosca, R. M., Savarino, J., Lee, C. C. W., and Thiemens, M. H.: Sulfate formation in sea-salt aerosols: Constraints from oxygen isotopes, J. Geophys. Res.-Atmos., 110, D10307, doi:10.1029/2004jd005659, 2005.

Allard, B. and Arsenie, I.: Abiotic reduction of mercury by humic substances in aquatic system - an important process for the mercury cycle, Water Air Soil Pollut., 56, 457-464, doi:10.1007/bf00342291, 1991.

Amos, H. M., Jacob, D. J., Holmes, C. D., Fisher, J. A., Wang, Q., Yantosca, R. M., Corbitt, E. S., Galarneau, E., Rutter, A. P., Gustin, M. S., Steffen, A., Schauer, J. J., Graydon, J. A., Louis, V. L. St., Talbot, R. W., Edgerton, E. S., Zhang, Y., and Sunderland, E. M.: Gas-particle partitioning of atmospheric $\mathrm{Hg}$ (II) and its effect on global mercury deposition, Atmos. Chem. Phys., 12, 591-603, doi:10.5194/acp-12-591-2012, 2012.

Amyot, M., Mierle, G., Lean, D., and McQueen, D.: SunlightInduced Formation of Dissolved Gaseous Mercury in Lake Waters, Environ. Sci. Technol., 28, 2366-2371, doi:10.1021/es00062a022, 1994.

Amyot, M., Lean, D. R. S., Poissant, L., and Doyon, M. R.: Distribution and transformation of elemental mercury in the St. Lawrence River and Lake Ontario, Can. J. Fish. Aquat. Sci., 57, 155-163, doi:10.1139/Cjfas-57-S1-155, 2000.

Angot, H., Barret, M., Magand, O., Ramonet, M., and Dommergue, A.: A 2-year record of atmospheric mercury species at a background Southern Hemisphere station on Amsterdam Island, Atmos. Chem. Phys., 14, 11461-11473, doi:10.5194/acp14-11461-2014, 2014.

Angot, H., Dastoor, A., De Simone, F., Gårdfeldt, K., Gencarelli, C. N., Hedgecock, I. M., Langer, S., Magand, O., Mastromonaco, M. N., Nordstrøm, C., Pfaffhuber, K. A., Pirrone, N., Ryjkov, A., Selin, N. E., Skov, H., Song, S., Sprovieri, F., Steffen, A., Toyota, K., Travnikov, O., Yang, X., and Dommergue, A.: Chemical cycling and deposition of atmospheric mercury in polar regions: review of recent measurements and comparison with models, Atmos. Chem. Phys., 16, 10735-10763, doi:10.5194/acp-1610735-2016, 2016.

Ariya, P. A., Khalizov, A., and Gidas, A.: Reactions of gaseous mercury with atomic and molecular halogens: Kinetics, product studies, and atmospheric implications, J. Phys. Chem. A, 106, 73107320, doi:10.1021/jp020719o, 2002.

Ariya, P. A., Amyot, M., Dastoor, A., Deeds, D., Feinberg, A., Kos, G., Poulain, A., Ryjkov, A., Semeniuk, K., Subir, M., and Toyota, K.: Mercury Physicochemical and Biogeochemical Transformation in the Atmosphere and at Atmospheric Interfaces: A Review and Future Directions, Chem. Rev., 115, 3760-3802, doi:10.1021/cr500667e, 2015.

Auzmendi-Murua, I., Castillo, A., and Bozzelli, J.: Mercury Oxidation via Chlorine, Bromine, and Iodine under Atmospheric Conditions: Thermochemistry and Kinetics, J. Phys. Chem. A, 118, 2959-2975, doi:10.1021/jp412654s, 2014.

Balabanov, N. and Peterson, K.: Mercury and reactive halogens: The thermochemistry of $\mathrm{Hg}^{+}\{\mathrm{Cl}-2, \mathrm{Br}-2, \mathrm{BrCl}, \mathrm{ClO}$, and $\mathrm{BrO}\}$, J. Phys. Chem. A, 107, 7465-7470, doi:10.1021/jp035547p, 2003.

Balabanov, N., Shepler, B., and Peterson, K.: Accurate global potential energy surface and reaction dynamics for the ground state of $\mathrm{HgBr}_{2}$, J. Phys. Chem. A, 109, 8765-8773, doi:10.1021/jp0534151, 2005.

Bash, J., Carlton, A., Hutzell, W., and Bullock, O.: Regional Air Quality Model Application of the Aqueous-Phase Photo Reduction of Atmospheric Oxidized Mercury by Dicarboxylic Acids, Atmosphere, 5, 1-15, doi:10.3390/atmos5010001, 2014.

Bergan, T. and Rodhe, H.: Oxidation of elemental mercury in the atmosphere; Constraints imposed by global scale modelling, J. Atmos. Chem., 40, 191-212, doi:10.1023/a:1011929927896, 2001.

Bey, I., Jacob, D. J., Yantosca, R. M., Logan, J. A., Field, B. D., Fiore, A. M., Li, Q. B., Liu, H. G. Y., Mickley, L. J., and Schultz, M. G.: Global modeling of tropospheric chemistry with assimilated meteorology: Model description and evaluation, J. Geophys. Res.-Atmos., 106, 23073-23095, doi:10.1029/2001jd000807, 2001.

Bieser, J., Slemr, F., Ambrose, J., Brenninkmeijer, C., Brooks, S., Dastoor, A., DeSimone, F., Ebinghaus, R., Gencarelli, C., Geyer, B., Gratz, L. E., Hedgecock, I. M., Jaffe, D., Kelley, P., Lin, C.-J., Matthias, V., Ryjkov, A., Selin, N., Song, S., Travnikov, O., Weigelt, A., Luke, W., Ren, X., Zahn, A., Yang, X., Zhu, Y., and Pirrone, N.: Multi-model study of mercury dispersion in the atmosphere: Vertical distribution of mercury species, Atmos. Chem. Phys. Discuss., doi:10.5194/acp-2016-1074, in review, 2016.

Brenninkmeijer, C. A. M., Crutzen, P., Boumard, F., Dauer, T., Dix, B., Ebinghaus, R., Filippi, D., Fischer, H., Franke, H., Frieß, U., Heintzenberg, J., Helleis, F., Hermann, M., Kock, H. H., Koeppel, C., Lelieveld, J., Leuenberger, M., Martinsson, B. G., Miemczyk, S., Moret, H. P., Nguyen, H. N., Nyfeler, P., Oram, D., O’Sullivan, D., Penkett, S., Platt, U., Pupek, M., Ramonet, M., Randa, B., Reichelt, M., Rhee, T. S., Rohwer, J., Rosenfeld, K., Scharffe, D., Schlager, H., Schumann, U., Slemr, F., Sprung, D., Stock, P., Thaler, R., Valentino, F., van Velthoven, P., Waibel, A., Wandel, A., Waschitschek, K., Wiedensohler, A., Xueref-Remy, I., Zahn, A., Zech, U., and Ziereis, H.: Civil Aircraft for the regular investigation of the atmosphere based on an instrumented container: The new CARIBIC system, Atmos. Chem. Phys., 7, 4953-4976, doi:10.5194/acp-7-4953-2007, 2007.

Bullock, O. R., Atkinson, D., Braverman, T., Civerolo, K., Dastoor, A., Davignon, D., Ku, J. Y., Lohman, K., Myers, T. C., Park, R. J., Seigneur, C., Selin, N. E., Sistla, G., and Vijayaraghavan, K.: The North American Mercury Model Intercomparison Study (NAMMIS): Study description and modelto-model comparisons, J. Geophys. Res.-Atmos., 113, D17310, doi:10.1029/2008jd009803, 2008.

Buxton, G., Greenstock, C., Helman, W., and Ross, A.: Critical Review of rate constants for reactions of hydrated electrons, hydrogen atoms and hydroxyl radicals $\left(\cdot \mathrm{OH} / \cdot \mathrm{O}^{-}\right)$in Aqueous Solution, J. Phys. Chem. Ref. Data, 17, 513-886, 1988.

Calvert, J. G. and Lindberg, S. E.: Mechanisms of mercury removal by $\mathrm{O}-3$ and $\mathrm{OH}$ in the atmosphere, Atmos. Environ., 39, 33553367, doi:10.1016/j.atmosenv.2005.01.055, 2005.

Considine, D. B., Logan, J. A., and Olsen, M. A.: Evaluation of near-tropopause ozone distributions in the Global Modeling Initiative combined stratosphere/troposphere model with ozonesonde data, Atmos. Chem. Phys., 8, 2365-2385, doi:10.5194/acp-8-2365-2008, 2008.

Cossa, D., Heimbürger, L.-E., Lannuzel, D., Rintoul, S. R., Butler, E. C. V., Bowie, A. R., Averty, B., Watson, R. J., and Remenyi, 
T.: Mercury in the Southern Ocean, Geochim. Cosmochim. Ac., 75, 4037-4052, doi:10.1016/j.gca.2011.05.001, 2011.

Costa, M. and Liss, P. S.: Photoreduction of mercury in sea water and its possible implications for $\mathrm{Hg}(0)$ air-sea fluxes, Mar. Chem., 68, 87-95, doi:10.1016/S0304-4203(99)00067-5, 1999.

Dastoor, A. P. and Larocque, Y.: Global circulation of atmospheric mercury: a modelling study, Atmos. Environ., 38, 147-161, doi:10.1016/j.atmosenv.2003.08.037, 2004.

Deeds, D., Banic, C., Lu, J., and Daggupaty, S.: Mercury speciation in a coal-fired power plant plume: An aircraft-based study of emissions from the 3640 MW Nanticoke Generating Station, Ontario, Canada, J. Geophys. Res.-Atmos., 118, 4919-4935, doi:10.1002/jgrd.50349, 2013.

De Simone, F., Gencarelli, C. N., Hedgecock, I. M., and Pirrone, N.: Global atmospheric cycle of mercury: a model study on the impact of oxidation mechanisms, Environ Sci Pollut R, 21, 41104123, 10.1007/s11356-013-2451-x, 2014.

Dibble, T. S., Zelie, M. J., and Mao, H.: Thermodynamics of reactions of $\mathrm{ClHg}$ and $\mathrm{BrHg}$ radicals with atmospherically abundant free radicals, Atmos. Chem. Phys., 12, 10271-10279, doi:10.5194/acp-12-10271-2012, 2012.

Dibble, T. S., Zelie, M. J., and Mao, H.: Corrigendum to “Thermodynamics of reactions of $\mathrm{ClHg}$ and $\mathrm{BrHg}$ radicals with atmospherically abundant free radicals" published in Atmos. Chem. Phys. 12, 10271-10279, 2012, Atmos. Chem. Phys., 13, 92119212, doi:10.5194/acp-13-9211-2013, 2013.

Dix, B., Baidara, S., Bresch, J., Hall, S., Schmidt, K., Wang, S., and Volkamer, R.: Detection of iodine monoxide in the tropical free troposphere, P. Natl. Acad. Sci. USA, 110, 2035-2040, doi:10.1073/pnas.1212386110, 2013.

Donohoue, D., Bauer, D., Cossairt, B., and Hynes, A.: Temperature and pressure dependent rate coefficients for the reaction of $\mathrm{Hg}$ with $\mathrm{Br}$ and the reaction of $\mathrm{Br}$ with $\mathrm{Br}$ : A pulsed laser photolysispulsed laser induced fluorescence study, J. Phys. Chem. A, 110, 6623-6632, doi:10.1021/jp054688j, 2006.

Donohoue, D. L., Bauer, D., and Hynes, A. J.: Temperature and pressure dependent rate coefficients for the reaction of $\mathrm{Hg}$ with $\mathrm{Cl}$ and the reaction of $\mathrm{Cl}$ with $\mathrm{Cl}$ : A pulsed laser photolysispulsed laser induced fluorescence study, J. Phys. Chem. A, 109, 7732-7741, doi:10.1021/jp054688j, 2005.

Edgerton, E. S., Hartsell, B. E., and Jansen, J. J.: Mercury speciation in coal-fired power plant plumes observed at three surface sites in the southeastern US, Environ. Sci. Technol., 40, 4563-4570, doi:10.1021/es0515607, 2006.

Fan, S.-M. and Jacob, D. J.: Surface ozone depletion in Arctic spring sustained by bromine reactions on aerosols, Nature, 359, 522-524, 1992.

Feng, X., Wang, S., Qiu, G., He, T., Li, G., Li, Z., and Shang, L.: Total gaseous mercury exchange between water and air during cloudy weather conditions over Hongfeng Reservoir, Guizhou, China, J. Geophys. Res.-Atmos., 113, D15309, doi:10.1029/2007JD009600, 2008.

Fernandez, R. P., Salawitch, R. J., Kinnison, D. E., Lamarque, J.-F., and Saiz-Lopez, A.: Bromine partitioning in the tropical tropopause layer: implications for stratospheric injection, Atmos. Chem. Phys., 14, 13391-13410, doi:10.5194/acp-1413391-2014, 2014.

Fisher, J. A., Jacob, D. J., Soerensen, A. L., Amos, H. M., Steffen, A., and Sunderland, E. M.: Riverine source of Arctic Ocean mercury inferred from atmospheric observations, Nat. Geosci., 5, 499-504, doi:10.1038/ngeo1478, 2012.

Fisher, J. A., Jacob, D. J., Soerensen, A. L., Amos, H. M., Corbitt, E. S., Streets, D. G., Wang, Q. Q., Yantosca, R. M., and Sunderland, E. M.: Factors driving mercury variability in the Arctic atmosphere and ocean over the past 30 years, Global Biogeochem. Cy., 27, 1226-1235, doi:10.1002/2013GB004689, 2013.

Fitzgerald, W., Gill, G. A., and Hewitt, A. D.: Air-sea exchange of mercury, in: Trace metals in sea water, edited by: Wong, C. S., Boyle, E., Bruland, K. W., Burton, J. D., and Goldberg, E. D., Plenum Publishing Company, 1983.

Flora, J. R. V., Vidic, R. D., Liu, W., and Thurnau, R. C.: Modeling powdered activated carbon injection for the uptake of elemental mercury vapors, J. Air Waste Manage. Assoc., 48, 1051-1059, 1998.

Fu, X. W., Feng, X., Liang, P., Deliger, Zhang, H., Ji, J., and Liu, P.: Temporal trend and sources of speciated atmospheric mercury at Waliguan GAW station, Northwestern China, Atmos. Chem. Phys., 12, 1951-1964, doi:10.5194/acp-12-1951-2012, 2012a.

Fu, X. W., Feng, X., Shang, L. H., Wang, S. F., and Zhang, H.: Two years of measurements of atmospheric total gaseous mercury (TGM) at a remote site in Mt. Changbai area, Northeastern China, Atmos. Chem. Phys., 12, 4215-4226, doi:10.5194/acp12-4215-2012, $2012 b$.

Fu, X. W., Zhang, H., Yu, B., Wang, X., Lin, C.-J., and Feng, X. B.: Observations of atmospheric mercury in China: a critical review, Atmos. Chem. Phys., 15, 9455-9476, doi:10.5194/acp-15-94552015, 2015.

Fu, X., Yang, X., Lang, X., Zhou, J., Zhang, H., Yu, B., Yan, H., Lin, C.-J., and Feng, X.: Atmospheric wet and litterfall mercury deposition at urban and rural sites in China, Atmos. Chem. Phys., 16, 11547-11562, doi:10.5194/acp-16-11547-2016, 2016.

Gårdfeldt, K. and Jonsson, M.: Is bimolecular reduction of $\mathrm{Hg}(\mathrm{II})$ complexes possible in aqueous systems of environmental importance, J. Phys. Chem. A, 107, 4478-4482, doi:10.1021/jp0275342, 2003.

Gencarelli, C. N., De Simone, F., Hedgecock, I. M., Sprovieri, F., and Pirrone, N.: Development and application of a regional-scale atmospheric mercury model based on WRF/Chem: a Mediterranean area investigation, Environ. Sci. Pollut. R, 21, 4095-4109, doi:10.1007/s11356-013-2162-3, 2014.

Gionfriddo, C. M., Tate, M. T., Wick, R. R., Schultz, M. B., Zemla, A., Thelen, M. P., Schofield, R., Krabbenhoft, D. P., Holt, K. E., and Moreau, J. W.: Microbial mercury methylation in Antarctic sea ice, Nature Microbiology, 1, 16127, doi:10.1038/nmicrobiol.2016.127, 2016.

Gómez Martín, J. C., Mahajan, A. S., Hay, T. D., Prados-Roman, C., Ordonez, C., MacDonald, S. M., Plane, J. M. C., Sorribas, M., Gil, M., Mora, J. F. P., Reyes, M. V. A., Oram, D. E., Leedham, E., and Saiz-Lopez, A.: Iodine chemistry in the eastern Pacific marine boundary layer, J. Geophys. Res.-Atmos., 118, 887-904, doi:10.1002/jgrd.50132, 2013.

Goodsite, M., Plane, J., and Skov, H.: A theoretical study of the oxidation of $\mathrm{Hg}-0$ to $\mathrm{HgBr} 2$ in the troposphere, Environ. Sci. Technol., 38, 1772-1776, doi:10.1021/es034680s, 2004.

Gratz, L., Keeler, G., Blum, J., and Sherman, L.: Isotopic Composition and Fractionation of Mercury in Great Lakes Precipitation and Ambient Air, Environ. Sci. Technol., 44, 7764-7770, doi:10.1021/es100383w, 2010. 
Gratz, L. E., Ambrose, J. L., Jaffe, D. A., Shah, V., Jaegle, L., Stutz, J., Festa, J., Spolaor, M., Tsai, C., Selin, N. E., Song, S., Zhou, X., Weinheimer, A. J., Knapp, D. J., Montzka, D. D., Flocke, F. M., Campos, T. L., Apel, E., Hornbrook, R., Blake, N. J., Hall, S., Tyndall, G. S., Reeves, M., Stechman, D., and Stell, M.: Oxidation of mercury by bromine in the subtropical Pacific free troposphere, Geophys. Res. Lett., 42, 10494-10502, doi:10.1002/2015GL066645, 2015.

Greig, G., Gunning, H. E., and Strausz, O. P.: Reactions of Metal Atoms .3. Combination of Mercury and Iodine Atoms and Spectrum of HgI, J. Chem. Phys., 52, 4569, doi:10.1063/1.1673687, 1970.

Guentzel, J. L., Landing, W. M., Gill, G. A., and Pollman, C. D.: Processes influencing rainfall deposition of mercury in Florida, Environ. Sci. Technol., 35, 863-873, doi:10.1021/es001523, 2001

Gustin, M. S., Amos, H. M., Huang, J., Miller, M. B., and Heidecorn, K.: Measuring and modeling mercury in the atmosphere: a critical review, Atmos. Chem. Phys., 15, 5697-5713, doi:10.5194/acp-15-5697-2015, 2015.

Haitzer, M., Aiken, G. R., and Ryan, J. N.: Binding of mercury(II) to dissolved organic matter: The role of the mercuryto-DOM concentration ratio, Environ. Sci. Technol., 36, 35643570, doi:10.1021/Es025699i, 2002.

Hall, B.: The gas phase oxidation of elemental mercury by ozone, Water Air Soil Poll., 80, 301-315, 1995.

Hall, B. and Bloom, N.: Report to EPRI, Electric Power Research Institute, Palo Alto, CA, 1993.

Hamrud, M.: Residence Time and Spatial Variability for Gases in the Atmosphere, Tellus B, 35, 295-303, 1983.

Harris, D. C.: Quantitative Chemical Analysis, W. H. Freeman and Co., New York, 2002.

Heald, C. L., Coe, H., Jimenez, J. L., Weber, R. J., Bahreini, R., Middlebrook, A. M., Russell, L. M., Jolleys, M., Fu, T.-M., Allan, J. D., Bower, K. N., Capes, G., Crosier, J., Morgan, W. T., Robinson, N. H., Williams, P. I., Cubison, M. J., DeCarlo, P. F., and Dunlea, E. J.: Exploring the vertical profile of atmospheric organic aerosol: comparing 17 aircraft field campaigns with a global model, Atmos. Chem. Phys., 11, 12673-12696, doi:10.5194/acp-11-12673-2011, 2011.

Hedgecock, I. and Pirrone, N.: Mercury and photochemistry in the marine boundary layer-modelling studies suggest the in situ production of reactive gas phase mercury, Atmos. Environ., 35, 3055-3062, doi:10.1016/s1352-2310(01)00109-1, 2001.

Holmes, C. D., Jacob, D. J., and Yang, X.: Global lifetime of elemental mercury against oxidation by atomic bromine in the free troposphere, Geophys. Res. Lett., 33, L20808, doi:10.1029/2006g1027176, 2006.

Holmes, C. D., Jacob, D. J., Mason, R. P., and Jaffe, D. A.: Sources and deposition of reactive gaseous mercury in the marine atmosphere, Atmos. Environ., 43, 2278-2285, doi:10.1016/j.atmosenv.2009.01.051, 2009.

Holmes, C. D., Jacob, D. J., Corbitt, E. S., Mao, J., Yang, X., Talbot, R., and Slemr, F.: Global atmospheric model for mercury including oxidation by bromine atoms, Atmos. Chem. Phys., 10, 12037-12057, doi:10.5194/acp-10-12037-2010, 2010.

Holmes, C. D., Krishnamurthy, N. P., Caffrey, J. M., Landing, W. M., Edgerton, E. S., Knapp, K. R., and Nair, U. S.: Thunder- storms Increase Mercury Wet Deposition, Environ. Sci. Technol., 50, 9343-9350, doi:10.1021/acs.est.6b02586, 2016.

Horowitz, H. M., Jacob, D. J., Amos, H. M., Streets, D. G., and Sunderland, E. M.: Historical Mercury Releases from Commercial Products: Global Environmental Implications, Environ. Sci. Technol., 48, 10242-10250, doi:10.1021/es501337j, 2014.

Hudman, R. C., Jacob, D. J., Turquety, S., Leibensperger, E. M., Murray, L. T., Wu, S., Gilliland, A. B., Avery, M., Bertram, T. H., Brune, W., Cohen, R. C., Dibb, J. E., Flocke, F. M., Fried, A., Holloway, J., Neuman, J. A., Orville, R., Perring, A., Ren, X., Sachse, G. W., Singh, H. B., Swanson, A., and Wooldridge, P. J.: Surface and lightning sources of nitrogen oxides over the United States: Magnitudes, chemical evolution, and outflow, J. Geophys. Res.-Atmos., 112, D12S05, doi:10.1029/2006jd007912, 2007.

Huthwelker, T., Peter, T., Luo, B. P., Clegg, S. L., Carslaw, K. S., and Brimblecombe, P.: Solubility of $\mathrm{HOCl}$ in Water and Aqueous $\mathrm{H}_{2} \mathrm{SO}_{4}$ to Stratospheric Temperatures, J. Atmos. Chem., 21, 8195, doi:10.1007/Bf00712439, 1995.

Hynes, A. J., Donohoue, D. L., Goodsite, M. E., and Hedgecock, I. M.: Our Current Understanding of Major Chemical and Physical Processes Affecting Mercury Dynamics in the Atmosphere and At the Air-Water/Terrestrial Interfaces, in: Mercury Fate and Transport in the Global Atmosphere, edited by: Pirrone, N., and Mason, R., Springer Science+Business Media, LLC, 427-457, 2009.

Jacob, D., Field, B., Li, Q., Blake, D., de Gouw, J., Warneke, C., Hansel, A., Wisthaler, A., Singh, H., and Guenther, A.: Global budget of methanol: Constraints from atmospheric observations, J. Geophys. Res.-Atmos., 110, D08303, doi:10.1029/2004jd005172, 2005.

Jacob, D. J.: Chemistry of OH in Remote Clouds and Its Role in the Production of Formic-Acid and Peroxymonosulfate, J. Geophys. Res.-Atmos., 91, 9807-9826, doi:10.1029/Jd091id09p09807, 1986.

Jaffe, D. A., Lyman, S., Amos, H. M., Gustin, M. S., Huang, J. Y., Selin, N. E., Levin, L., ter Schure, A., Mason, R. P., Talbot, R., Rutter, A., Finley, B., Jaegle, L., Shah, V., McClure, C., Arnbrose, J., Gratz, L., Lindberg, S., Weiss-Penzias, P., Sheu, G. R., Feddersen, D., Horvat, M., Dastoor, A., Hynes, A. J., Mao, H. T., Sonke, J. E., Slemr, F., Fisher, J. A., Ebinghaus, R., Zhang, Y. X., and Edwards, G.: Progress on Understanding Atmospheric Mercury Hampered by Uncertain Measurements, Environ. Sci. Technol., 48, 7204-7206, doi:10.1021/es5026432, 2014.

Jiao, Y. and Dibble, T. S.: First kinetic study of the atmospherically important reactions $\mathrm{BrHg}^{\bullet}+\mathrm{NO}_{2}$ and $\mathrm{BrHg}^{\bullet}+\mathrm{HOO}$, Phys Chem. Chem. Phys., 19, 1826-1838, doi:10.1039/c6cp06276h, 2017.

Jones, C. P., Lyman, S. N., Jaffe, D. A., Allen, T., and O’Neil, T. L.: Detection and quantification of gas-phase oxidized mercury compounds by GC/MS, Atmos. Meas. Tech., 9, 2195-2205, doi:10.5194/amt-9-2195-2016, 2016.

Junge, C. E.: Residence Time and Variability of Tropospheric Trace Gases, Tellus, 26, 477-488, 1974.

Klimont, Z., Smith, S. J., and Cofala, J.: The last decade of global anthropogenic sulfur dioxide: 2000-2011 emissions, Environ. Res. Lett., 8, 014003, doi:10.1088/1748-9326/8/1/014003, 2013.

Lamborg, C., Fitzgerald, W., O'Donnell, J., and Torgersen, T.: A non-steady state box model of global-scale mercury biogeochemistry with interhemispheric atmospheric gradients, Ab- 
stracts of Papers of the American Chemical Society, 223, U520U520, 2002.

Lamsal, L. N., Krotkov, N. A., Celarier, E. A., Swartz, W. H., Pickering, K. E., Bucsela, E. J., Gleason, J. F., Martin, R. V., Philip, S., Irie, H., Cede, A., Herman, J., Weinheimer, A., Szykman, J. J., and Knepp, T. N.: Evaluation of OMI operational standard $\mathrm{NO}_{2}$ column retrievals using in situ and surface-based $\mathrm{NO}_{2}$ observations, Atmos. Chem. Phys., 14, 11587-11609, doi:10.5194/acp14-11587-2014, 2014.

Landis, M., Ryan, J., ter Schure, A., and Laudal, D.: Behavior of Mercury Emissions from a Commercial Coal-Fired Power Plant: The Relationship between Stack Speciation and NearField Plume Measurements, Environ. Sci. Technol., 48, 1354013548, doi:10.1021/es500783t, 2014.

Lee, T. G., Biswas, P., and Hedrick, E.: Overall kinetics of heterogeneous elemental mercury reactions on $\mathrm{TiO}_{2}$ sorbent particles with UV irradiation, Ind. Eng. Chem. Res., 43, 1411-1417, doi:10.1021/ie0303707, 2004.

Liang, Q., Stolarski, R. S., Kawa, S. R., Nielsen, J. E., Douglass, A. R., Rodriguez, J. M., Blake, D. R., Atlas, E. L., and Ott, L. E.: Finding the missing stratospheric Bry: a global modeling study of $\mathrm{CHBr}_{3}$ and $\mathrm{CH}_{2} \mathrm{Br}_{2}$, Atmos. Chem. Phys., 10, 2269-2286, doi:10.5194/acp-10-2269-2010, 2010.

Lin, C. and Pehkonen, S.: Aqueous free radical chemistry of mercury in the presence of iron oxides and ambient aerosol, Atmos. Environ., 31, 4125-4137, doi:10.1016/S1352-2310(97)00269-0, 1997.

Lin, C. and Pehkonen, S.: Oxidation of elemental mercury by aqueous chlorine $\left(\mathrm{HOCl} / \mathrm{OCl}^{-}\right)$: Implications for tropospheric mercury chemistry, J. Geophys. Res.-Atmos., 103, 28093-28102, doi:10.1029/98jd02304, 1998.

Lin, C. J., Pongprueksa, P., Lindberg, S. E., Pehkonen, S. O., Byun, D., and Jang, C.: Scientific uncertainties in atmospheric mercury models I: Model science evaluation, Atmos. Environ., 40, 29112928, doi:10.1016/j.atmosenv.2006.01.009, 2006.

Lin, J. T. and McElroy, M. B.: Impacts of boundary layer mixing on pollutant vertical profiles in the lower troposphere: Implications to satellite remote sensing, Atmos. Environ., 44, 17261739, doi:10.1016/j.atmosenv.2010.02.009, 2010.

Lin, J.-T., Liu, Z., Zhang, Q., Liu, H., Mao, J., and Zhuang, G.: Modeling uncertainties for tropospheric nitrogen dioxide columns affecting satellite-based inverse modeling of nitrogen oxides emissions, Atmos. Chem. Phys., 12, 12255-12275, doi:10.5194/acp-12-12255-2012, 2012.

Lindqvist, O. and Rodhe, H.: Atmospheric mercury - a review, Tellus B, 37, 136-159, 1985.

Liu, S. H., Yan, N. Q., Liu, Z. R., Qu, Z., Wang, P., Chang, S. G., and Miller, C.: Using bromine gas to enhance mercury removal from flue gas of coal-fired power plants, Environ. Sci. Technol., 41, 1405-1412, doi:10.1021/es061705p, 2007.

Lohman, K., Seigneur, C., Edgerton, E., and Jansen, J.: Modeling mercury in power plant plumes, Environ. Sci. Technol., 40, 3848-3854, doi:10.1021/es051556v, 2006.

Lyman, S. and Jaffe, D.: Formation and fate of oxidized mercury in the upper troposphere and lower stratosphere, Nat. Geosci., 5, 114-117, doi:10.1038/ngeo1353, 2012.

Mao, J., Jacob, D. J., Evans, M. J., Olson, J. R., Ren, X., Brune, W. H., Clair, J. M. St., Crounse, J. D., Spencer, K. M., Beaver, M. R., Wennberg, P. O., Cubison, M. J., Jimenez, J. L., Fried, A.,
Weibring, P., Walega, J. G., Hall, S. R., Weinheimer, A. J., Cohen, R. C., Chen, G., Crawford, J. H., McNaughton, C., Clarke, A. D., Jaeglé, L., Fisher, J. A., Yantosca, R. M., Le Sager, P., and Carouge, C.: Chemistry of hydrogen oxide radicals $\left(\mathrm{HO}_{x}\right)$ in the Arctic troposphere in spring, Atmos. Chem. Phys., 10, 5823 5838, doi:10.5194/acp-10-5823-2010, 2010.

Mason, R. P., Lawson, N. M., and Sheu, G. R.: Mercury in the Atlantic Ocean: factors controlling air-sea exchange of mercury and its distribution in the upper waters, Deep-Sea Res. Pt. II, 48, 2829-2853, doi:10.1016/S0967-0645(01)00020-0, 2001.

Marais, E. A., Jacob, D. J., Kurosu, T. P., Chance, K., Murphy, J. G., Reeves, C., Mills, G., Casadio, S., Millet, D. B., Barkley, M. P., Paulot, F., and Mao, J.: Isoprene emissions in Africa inferred from OMI observations of formaldehyde columns, Atmos. Chem. Phys., 12, 6219-6235, doi:10.5194/acp-12-62192012, 2012.

Martin, R. V., Sioris, C. E., Chance, K., Ryerson, T. B., Bertram, T. H., Wooldridge, P. J., Cohen, R. C., Neuman, J. A., Swanson, A., and Flocke, F. M.: Evaluation of space-based con- straints on global nitrogen oxide emissions with regional aircraft measurements over and downwind of eastern North America, J. Geophys. Res., 111, D15308, doi:10.1029/2005JD006680, 2006.

Maya, J.: Ultraviolet absorption cross sections of $\mathrm{HgI}_{2}, \mathrm{HgBr}_{2}$, and tin (II) valid vapors, J. Chem. Phys., 67, 4976-4980, 1977.

Muntean, M., Janssens-Maenhout, G., Song, S. J., Selin, N. E., Olivier, J. G. J., Guizzardi, D., Maas, R., and Dentener, F.: Trend analysis from 1970 to 2008 and model evaluation of EDGARv4 global gridded anthropogenic mercury emissions, Sci. Total Environ., 494, 337-350, doi:10.1016/j.scitotenv.2014.06.014, 2014.

Munthe, J.: Aqueous oxidation of elemental $\mathrm{Hg}$ by $\mathrm{O}_{3}$, Atmos. Environ. A-Gen., 26, 1461-1468, doi:10.1016/0960-1686(92)901314, 1992.

Munthe, J. and McElroy, W. J.: Some aqueous reactions of potential importance in the atmospheric chemistry of mercury, Atmos. Environ. A-Gen., 26, 553-557, doi:10.1016/0960-1686(92)90168k, 1992.

Murphy, D. M., Anderson, J. R., Quinn, P. K., McInnes, L. M., Brechtel, F. J., Kreidenweis, S. M., Middlebrook, A. M., Posfai, M., Thomson, D. S., and Buseck, P. R.: Influence of sea-salt on aerosol radiative properties in the Southern Ocean marine boundary layer, Nature, 392, 62-65, doi:10.1038/32138, 1998.

Murphy, D. M., Hudson, P. K., Thomson, D. S., Sheridan, P. J., and Wilson, J. C.: Observations of mercury-containing aerosols, Environ. Sci. Technol., 40, 3163-3167, doi:10.1021/es052385x, 2006.

Murray, L. T., Jacob, D. J., Logan, J. A., Hudman, R. C., and Koshak, W. J.: Optimized regional and interannual variability of lightning in a global chemical transport model constrained by LIS/OTD satellite data, J. Geophys. Res.-Atmos., 117, D20307, doi:10.1029/2012jd017934, 2012.

Nguyen, H. T., Kim, K.-H., Kim, M.-Y., Hong, S., Youn, Y.-H., Shon, Z.-H., and Lee, J. S.: Monitoring of atmospheric mercury at a global atmospheric watch (GAW) site on An-Myun Island, Korea, Water Air Soil Poll., 185, 149-164, doi:10.1007/s11270007-9438-5, 2007.

O’Driscoll, N., Siciliano, S., Lean, D., and Amyot, M.: Gross photoreduction kinetics of mercury in temperate freshwater lakes and rivers: Application to a general model of DGM dynamics, 
Environ. Sci. Technol., 40, 837-843, doi:10.1021/es051062y, 2006.

O’Driscoll, N. J., Lean, D. R. S., Loseto, L. L., Carignan, R., and Siciliano, S. D.: Effect of dissolved organic carbon on the photoproduction of dissolved gaseous mercury in lakes: Potential impacts of forestry, Environ. Sci. Technol., 38, 2664-2672, doi:10.1021/Es034702a, 2004.

Orbe, C., Holzer, M., Polvani, L. M., Waugh, D. W., Li, F., Oman, L. D., and Newman, P. A.: Seasonal ventilation of the stratosphere: Robust diagnostics from one-way flux distributions, J. Geophys. Res.-Atmos., 119, 293-306, doi:10.1002/2013JD020213, 2014.

Pal, B. and Ariya, P. A.: Gas-phase HO center dot-Initiated reactions of elemental mercury: Kinetics, product studies, and atmospheric implications, Environ. Sci. Technol., 38, 5555-5566, doi:10.1021/es0494353, 2004.

Parrella, J. P., Jacob, D. J., Liang, Q., Zhang, Y., Mickley, L. J., Miller, B., Evans, M. J., Yang, X., Pyle, J. A., Theys, N., and Van Roozendael, M.: Tropospheric bromine chemistry: implications for present and pre-industrial ozone and mercury, Atmos. Chem. Phys., 12, 6723-6740, doi:10.5194/acp-12-6723-2012, 2012.

Pehkonen, S. O. and Lin, C. J.: Aqueous photochemistry of mercury with organic acids, J. Air Waste Manage. Assoc., 48, 144-150, 1998.

Peleg, M., Tas, E., Obrist, D., Matveev, V., Moore, C., Gabay, M., and Luria, M.: Observational Evidence for Involvement of $\mathrm{Ni}$ trate Radicals in Nighttime Oxidation of Mercury, Environ. Sci. Technol., 49, 14008-14018, doi:10.1021/acs.est.5b03894, 2015.

Ploeger, F. and Birner, T.: Seasonal and inter-annual variability of lower stratospheric age of air spectra, Atmos. Chem. Phys., 16, 10195-10213, doi:10.5194/acp-16-10195-2016, 2016.

Prados-Roman, C., Cuevas, C. A., Hay, T., Fernandez, R. P., Mahajan, A. S., Royer, S.-J., Galí, M., Simó, R., Dachs, J., Großmann, K., Kinnison, D. E., Lamarque, J.-F., and Saiz-Lopez, A.: Iodine oxide in the global marine boundary layer, Atmos. Chem. Phys., 15, 583-593, doi:10.5194/acp-15-583-2015, 2015.

Pye, H. O. T., Chan, A. W. H., Barkley, M. P., and Seinfeld, J. H.: Global modeling of organic aerosol: the importance of reactive nitrogen $\left(\mathrm{NO}_{x}\right.$ and $\left.\mathrm{NO}_{3}\right)$, Atmos. Chem. Phys., 10, 1126111276, doi:10.5194/acp-10-11261-2010, 2010.

Qu, Z., Yan, N. Q., Liu, P., Jia, J. P., and Yang, S. J.: The role of iodine monochloride for the oxidation of elemental mercury, J. Hazard. Mater., 183, 132-137, doi:10.1016/j.jhazmat.2010.06.126, 2010.

Raofie, F., Snider, G., and Ariya, P. A.: Reaction of gaseous mercury with molecular iodine, atomic iodine, and iodine oxide radicals Kinetics, product studies, and atmospheric implications, Can. J. Chemistry, 86, 811-820, doi:10.1139/V08-088, 2008.

Ravichandran, M.: Interactions between mercury and dissolved organic matter - a review, Chemosphere, 55, 319-331, doi:10.1016/j.chemosphere.2003.11.011, 2004.

Rutter, A. P., Shakya, K. M., Lehr, R., Schauer, J. J., and Griffin, R. J.: Oxidation of gaseous elemental mercury in the presence of secondary organic aerosols, Atmos. Environ., 59, 86-92, doi:10.1016/j.atmosenv.2012.05.009, 2012.

Sakata, M. and Asakura, K.: Estimating contribution of precipitation scavenging of atmospheric particulate mercury to mercury wet deposition in Japan, Atmos. Environ., 41, 1669-1680, doi:10.1016/j.atmosenv.2006.10.031, 2007.
Sanemasa, I.: Solubility of Elemental Mercury-Vapor in Water, B. Chem. Soc. Jpn., 48, 1795-1798, doi:10.1246/Bcsj.48.1795, 1975.

Schmidt, J. A., Jacob, D. J., Horowitz, H. M., Hu, L., Sherwen, T., Evans, M. J., Liang, Q., Suleiman, R. M., Oram, D. E., Le Breton, M., Percival, C. J., Wang, S., and Volkamer, R.: Modeling the observed tropospheric BrO background: Importance of multiphase chemistry and implications for ozone, $\mathrm{OH}$, and mercury, J. Geophys. Res.-Atmos., 121, 11819-11835, doi:10.1002/2015JD024229, 2016.

Schoeberl, M. R., Douglass, A. R., Zhu, Z. X., and Pawson, S.: A comparison of the lower stratospheric age spectra derived from a general circulation model and two data assimilation systems, J. Geophys. Res.-Atmos., 108, 4113, doi:10.1029/2002jd002652, 2003.

Schroeder, W. H., Anlauf, K. G., Barrie, L. A., Lu, J. Y., Steffen, A., Schneeberger, D. R., and Berg, T.: Arctic springtime depletion of mercury, Nature, 394, 331-332, doi:10.1038/28530, 1998.

Selin, N. E. and Jacob, D. J.: Seasonal and spatial patterns of mercury wet deposition in the United States: Constraints on the contribution from North American anthropogenic sources, Atmos. Environ., 42, 5193-5204, doi:10.1016/j.atmosenv.2008.02.069, 2008.

Selin, N. E., Jacob, D. J., Park, R. J., Yantosca, R. M., Strode, S., Jaegle, L., and Jaffe, D.: Chemical cycling and deposition of atmospheric mercury: Global constraints from observations, J. Geophys. Res.-Atmos., 112, D02308, doi:10.1029/2006jd007450, 2007.

Selin, N. E., Jacob, D. J., Yantosca, R. M., Strode, S., Jaegle, L., and Sunderland, E. M.: Global 3-D land-ocean-atmosphere model for mercury: Present-day versus preindustrial cycles and anthropogenic enrichment factors for deposition, Global Biogeochem. Cy., 22, GB2011, doi:10.1029/2007gb003040, 2008.

Shah, V., Jaeglé, L., Gratz, L. E., Ambrose, J. L., Jaffe, D. A., Selin, N. E., Song, S., Campos, T. L., Flocke, F. M., Reeves, M., Stechman, D., Stell, M., Festa, J., Stutz, J., Weinheimer, A. J., Knapp, D. J., Montzka, D. D., Tyndall, G. S., Apel, E. C., Hornbrook, R. S., Hills, A. J., Riemer, D. D., Blake, N. J., Cantrell, C. A., and Mauldin III, R. L.: Origin of oxidized mercury in the summertime free troposphere over the southeastern US, Atmos. Chem. Phys., 16, 1511-1530, doi:10.5194/acp-16-1511-2016, 2016.

Shepler, B. C. and Peterson, K. A.: Mercury monoxide: A systematic investigation of its ground electronic state, J. Phys. Chem. A, 107, 1783-1787, doi:10.1021/jp027512f, 2003.

Sheu, G. R., Lin, N. H., Wang, J. L., Lee, C. T., Yang, C. F. O., and Wang, S. H.: Temporal distribution and potential sources of atmospheric mercury measured at a high-elevation background station in Taiwan, Atmos. Environ., 44, 2393-2400, doi:10.1016/j.atmosenv.2010.04.009, 2010.

$\mathrm{Si}$, L. and Ariya, P. A.: Reduction of oxidized mercury species by dicarboxylic acids $(\mathrm{C}(2)-\mathrm{C}(4))$ : Kinetic and product studies, Environ. Sci. Technol., 42, 5150-5155, doi:10.1021/es800552z, 2008.

Simpson, W. R., Brown, S. S., Saiz-Lopez, A., Thornton, J. A., and von Glasow, R.: Tropospheric Halogen Chemistry: Sources, Cycling, and Impacts, Chem. Rev., 115, 4035-4062, doi:10.1021/cr5006638, 2015.

Singh, H. B., Salas, L., Herlth, D., Kolyer, R., Czech, E., Avery, M., Crawford, J. H., Pierce, R. B., Sachse, G. W., Blake, D. R., Co- 
hen, R. C., Bertram, T. H., Perring, A., Wooldridge, P. J., Dibb, J., Huey, G., Hudman, R. C., Turquety, S., Emmons, L. K., Flocke, F., Tang, Y., Carmichael, G. R., and Horowitz, L. W.: Reactive nitrogen distribution and partitioning in the North American troposphere and lowermost stratosphere, J. Geophys. Res.-Atmos., 112, D12S04, doi:10.1029/2006jd007664, 2007.

Slemr, F., Seiler, W., and Schuster, G.: Latitudinal distribution of mercury over the Atlantic-Ocean, J. Geophys. Res.-Oceans, 86, 1159-1166, doi:10.1029/JC086iC02p01159, 1981.

Slemr, F., Ebinghaus, R., Brenninkmeijer, C. A. M., Hermann, M., Kock, H. H., Martinsson, B. G., Schuck, T., Sprung, D., van Velthoven, P., Zahn, A., and Ziereis, H.: Gaseous mercury distribution in the upper troposphere and lower stratosphere observed onboard the CARIBIC passenger aircraft, Atmos. Chem. Phys., 9, 1957-1969, doi:10.5194/acp-9-1957-2009, 2009.

Slemr, F., Weigelt, A., Ebinghaus, R., Brenninkmeijer, C., Baker, A., Schuck, T., Rauthe-Schoch, A., Riede, H., Leedham, E., Hermann, M., van Velthoven, P., Oram, D., O’Sullivan, D., Dyroff, C., Zahn, A., and Ziereis, H.: Mercury Plumes in the Global Upper Troposphere Observed during Flights with the CARIBIC Observatory from May 2005 until June 2013, Atmosphere, 5, 342369, doi:10.3390/atmos5020342, 2014.

Slemr, F., Angot, H., Dommergue, A., Magand, O., Barret, M., Weigelt, A., Ebinghaus, R., Brunke, E.-G., Pfaffhuber, K. A., Edwards, G., Howard, D., Powell, J., Keywood, M., and Wang, F.: Comparison of mercury concentrations measured at several sites in the Southern Hemisphere, Atmos. Chem. Phys., 15, 31253133, doi:10.5194/acp-15-3125-2015, 2015.

Slemr, F., Weigelt, A., Ebinghaus, R., Kock, H. H., Bödewadt, J., Brenninkmeijer, C. A. M., Rauthe-Schöch, A., Weber, S., Hermann, M., Becker, J., Zahn, A., and Martinsson, B.: Atmospheric mercury measurements onboard the CARIBIC passenger aircraft, Atmos. Meas. Tech., 9, 2291-2302, doi:10.5194/amt-92291-2016, 2016.

Smith-Downey, N. V., Sunderland, E. M., and Jacob, D. J.: Anthropogenic impacts on global storage and emissions of mercury from terrestrial soils: Insights from a new global model, J. Geophys. Res.-Biogeo., 115, G03008, doi:10.1029/2009jg001124, 2010.

Soerensen, A. L., Sunderland, E. M., Holmes, C. D., Jacob, D. J., Yantosca, R. M., Skov, H., Christensen, J. H., Strode, S. A., and Mason, R. P.: An Improved Global Model for Air-Sea Exchange of Mercury: High Concentrations over the North Atlantic, Environ. Sci. Technol., 44, 8574-8580, doi:10.1021/Es102032g, 2010.

Snider, G., Raofie, F., and Ariya, P.: Effects of relative humidity and $\mathrm{CO}(\mathrm{g})$ on the $\mathrm{O}(3)$-initiated oxidation reaction of $\mathrm{Hg}(0)(\mathrm{g})$ : kinetic \& product studies, Phys. Chem. Chem. Phys., 10, 56165623, doi:10.1039/b801226a, 2008.

Soerensen, A. L., Mason, R. P., Balcom, P. H., and Sunderland, E. M.: Drivers of Surface Ocean Mercury Concentrations and AirSea Exchange in the West Atlantic Ocean, Environ. Sci. Technol., 47, 7757-7765, doi:10.1021/es401354q, 2013.

Soerensen, A. L., Mason, R. P., Balcom, P. H., Jacob, D. J., Zhang, Y. X., Kuss, J., and Sunderland, E. M.: Elemental Mercury Concentrations and Fluxes in the Tropical Atmosphere and Ocean, Environ. Sci. Technol., 48, 11312-11319, doi:10.1021/es503109p, 2014.
Song, S., Selin, N. E., Soerensen, A. L., Angot, H., Artz, R., Brooks, S., Brunke, E.-G., Conley, G., Dommergue, A., Ebinghaus, R., Holsen, T. M., Jaffe, D. A., Kang, S., Kelley, P., Luke, W. T., Magand, O., Marumoto, K., Pfaffhuber, K. A., Ren, X., Sheu, G.-R., Slemr, F., Warneke, T., Weigelt, A., Weiss-Penzias, P., Wip, D. C., and Zhang, Q.: Top-down constraints on atmospheric mercury emissions and implications for global biogeochemical cycling, Atmos. Chem. Phys., 15, 7103-7125, doi:10.5194/acp-157103-2015, 2015.

Sonke, J.: A global model of mass independent mercury stable isotope fractionation, Geochim. Cosmochim. Ac., 75, 4577-4590, doi:10.1016/j.gca.2011.05.027, 2011.

Sonke, J. E., Marusczak, N., and Fu, X. W.: A stable isotope view of the atmospheric Hg cycle, Goldschmidt, Prague, Czech Republic, 2015.

Steffen, A., Douglas, T., Amyot, M., Ariya, P., Aspmo, K., Berg, T., Bottenheim, J., Brooks, S., Cobbett, F., Dastoor, A., Dommergue, A., Ebinghaus, R., Ferrari, C., Gardfeldt, K., Goodsite, M. E., Lean, D., Poulain, A. J., Scherz, C., Skov, H., Sommar, J., and Temme, C.: A synthesis of atmospheric mercury depletion event chemistry in the atmosphere and snow, Atmos. Chem. Phys., 8, 1445-1482, doi:10.5194/acp-8-1445-2008, 2008.

Strahan, S. E., Duncan, B. N., and Hoor, P.: Observationally derived transport diagnostics for the lowermost stratosphere and their application to the GMI chemistry and transport model, Atmos. Chem. Phys., 7, 2435-2445, doi:10.5194/acp-7-2435-2007, 2007.

Strode, S. A., Jaegle, L., Jaffe, D. A., Swartzendruber, P. C., Selin, N. E., Holmes, C., and Yantosca, R. M.: TransPacific transport of mercury, J. Res.-Atmos., 113, D15305, doi:10.1029/2007jd009428, 2008.

Subir, M., Ariya, P. A., and Dastoor, A. P.: A review of uncertainties in atmospheric modeling of mercury chemistry I. Uncertainties in existing kinetic parameters - Fundamental limitations and the importance of heterogeneous chemistry, Atmos. Environ., 45, 5664-5676, doi:10.1016/j.atmosenv.2011.04.046, 2011.

Sumner, A. L., Spicer, C. W., Statola, J., Mangaraj, R., Cowen, K. A., and Landis, M. S.: Environmental chamber studies of mercury reactions in the atmosphere, in: Dynamics of Mercury Pollution on Regional and Global Scales: Atmospheric Processes and Human Exposures Around the World, edited by: Pirrone, N., and Mahaffey, K. R., Springer, USA, 193-212, 2005.

Sunderland, E. M. and Mason, R. P.: Human impacts on open ocean mercury concentrations, Global Biogeochem. Cyc., 21, GB4022, doi:10.1029/2006gb002876, 2007.

Talbot, R., Mao, H., Scheuer, E., Dibb, J., and Avery, M.: Total depletion of $\mathrm{Hg}^{0}$ in the upper troposphere-lower stratosphere, Geophys. Res. Lett., 34, L23804, doi:10.1029/2007g1031366, 2007.

Tan, W. W., Geller, M. A., Pawson, S., and da Silva, A.: A case study of excessive subtropical transport in the stratosphere of a data assimilation system, J. Geophys. Res.-Atmos., 109, D11102, doi:10.1029/2003jd004057, 2004.

Theys, N., Van Roozendael, M., Hendrick, F., Yang, X., De Smedt, I., Richter, A., Begoin, M., Errera, Q., Johnston, P. V., Kreher, K., and De Mazière, M.: Global observations of tropospheric BrO columns using GOME-2 satellite data, Atmos. Chem. Phys., 11, 1791-1811, doi:10.5194/acp-11-1791-2011, 2011.

Tossell, J. A.: Calculation of the energetics for the oligomerization of gas phase $\mathrm{HgO}$ and $\mathrm{HgS}$ and for the solvolysis of 
crystalline $\mathrm{HgO}$ and $\mathrm{HgS}$, J. Phys. Chem. A, 110, 2571-2578, doi:10.1021/jp056280s, 2006.

Travis, K. R., Jacob, D. J., Fisher, J. A., Kim, P. S., Marais, E. A., Zhu, L., Yu, K., Miller, C. C., Yantosca, R. M., Sulprizio, M. P., Thompson, A. M., Wennberg, P. O., Crounse, J. D., St. Clair, J. M., Cohen, R. C., Laughner, J. L., Dibb, J. E., Hall, S. R., Ullmann, K., Wolfe, G. M., Pollack, I. B., Peischl, J., Neuman, J. A., and Zhou, X.: Why do models overestimate surface ozone in the Southeast United States?, Atmos. Chem. Phys., 16, 1356113577, doi:10.5194/acp-16-13561-2016, 2016.

Travnikov, O. and Ilyin, I.: The EMEP/MSC-E Mercury Modeling System, Mercury Fate and Transport in the Global Atmosphere, 47, 571-587, doi:10.1007/978-0-387-93958-2_20, 2009.

van Loon, L. L., Mader, E. A., and Scott, S. L.: Sulfite stabilization and reduction of the aqueous mercuric ion: Kinetic determination of sequential formation constants, J. Phys. Chem. A, 105, 31903195, doi:10.1021/jp003803h, 2001.

Vidic, R. D., Chang, M. T., and Thurnau, R. C.: Kinetics of vaporphase mercury uptake by virgin and sulfur-impregnated activated carbons, J. Air Waste Manage. As., 48, 247-255, 1998

Volkamer, R., Baidar, S., Campos, T. L., Coburn, S., DiGangi, J. P., Dix, B., Eloranta, E. W., Koenig, T. K., Morley, B., Ortega, I., Pierce, B. R., Reeves, M., Sinreich, R., Wang, S., Zondlo, M. A., and Romashkin, P. A.: Aircraft measurements of BrO, IO, glyoxal, $\mathrm{NO}_{2}, \mathrm{H}_{2} \mathrm{O}, \mathrm{O}_{2}-\mathrm{O}_{2}$ and aerosol extinction profiles in the tropics: comparison with aircraft-/ship-based in situ and lidar measurements, Atmos. Meas. Tech., 8, 2121-2148, doi:10.5194/amt-8-2121-2015, 2015.

Wan, Q., Feng, X., Lu, J., Zheng, W., Song, X., Han, S., and Xu, H.: Atmospheric mercury in Changbai Mountain area, northeastern China I. The seasonal distribution pattern of total gaseous mercury and its potential sources, Environ. Res., 109, 201-206, doi:10.1016/j.envres.2008.12.001, 2009.

Wang, F., Saiz-Lopez, A., Mahajan, A. S., Gómez Martín, J. C., Armstrong, D., Lemes, M., Hay, T., and Prados-Roman, C.: Enhanced production of oxidised mercury over the tropical Pacific Ocean: a key missing oxidation pathway, Atmos. Chem. Phys., 14, 1323-1335, doi:10.5194/acp-14-1323-2014, 2014.

Wang, S. Y., Schmidt, J. A., Baidar, S., Coburn, S., Dix, B., Koenig, T. K., Apel, E., Bowdalo, D., Campos, T. L., Eloranta, E., Evans, M. J., DiGangi, J. P., Zondlo, M. A., Gao, R. S., Haggerty, J. A., Hall, S. R., Hornbrook, R. S., Jacob, D., Morley, B., Pierce, B., Reeves, M., Romashkin, P., ter Schure, A., and Volkamer, R.: Active and widespread halogen chemistry in the tropical and subtropical free troposphere, P. Natl. Acad. Sci. USA, 112, 92819286, doi:10.1073/pnas.1505142112, 2015.

Wang, Z. and Pehkonen, S.: Oxidation of elemental mercury by aqueous bromine: atmospheric implications, Atmos. Environ., 38, 3675-3688, doi:10.1016/j.atmosenv.2004.02.059, 2004.

Weigelt, A., Slemr, F., Ebinghaus, R., Pirrone, N., Bieser, J., Bödewadt, J., Esposito, G., and van Velthoven, P. F. J.: Mercury emissions of a coal-fired power plant in Germany, Atmos. Chem. Phys., 16, 13653-13668, doi:10.5194/acp-16-13653-2016, 2016.

Weiss-Penzias, P., Jaffe, D., Swartzendruber, P., Hafner, W., Chand, D., and Prestbo, E.: Quantifying Asian and biomass burning sources of mercury using the $\mathrm{Hg} / \mathrm{CO}$ ratio in pollution plumes observed at the Mount Bachelor Observatory, Atmos. Environ., 41, 4366-4379, doi:10.1016/j.atmosenv.2007.01.058, 2007.
Weiss-Penzias, P., Amos, H. M., Selin, N. E., Gustin, M. S., Jaffe, D. A., Obrist, D., Sheu, G.-R., and Giang, A.: Use of a global model to understand speciated atmospheric mercury observations at five high-elevation sites, Atmos. Chem. Phys., 15, 11611173, doi:10.5194/acp-15-1161-2015, 2015.

Whalin, L. and Mason, R.: A new method for the investigation of mercury redox chemistry in natural waters utilizing deflatable Teflon (R) bags and additions of isotopically labeled mercury, Anal. Chim. Ac., 558, 211-221, doi:10.1016/j.aca.2005.10.070, 2006.

Whalin, L., Kim, E. H., and Mason, R.: Factors influencing the oxidation, reduction, methylation and demethylation of mercury species in coastal waters, Mar. Chem., 107, 278-294, doi:10.1016/j.marchem.2007.04.002, 2007.

Wilcox, J.: A Kinetic Investigation of High-Temperature Mercury Oxidation by Chlorine, J. Phys. Chem. A, 113, 6633-6639, doi:10.1021/jp901050d, 2009.

Xiao, Y., Jacob, D. J., and Turquety, S.: Atmospheric acetylene and its relationship with $\mathrm{CO}$ as an indicator of air mass age, J. Geophys. Res., 112, D12305, doi:10.1029/2006JD008268, 2007.

Xiao, Z. F., Stromberg, D., and Lindqvist, O.: Influence of Humic Substances on Photolysis of Divalent Mercury in Aqueous-Solution, Water Air Soil Pollut., 80, 789-798, doi:10.1007/Bf01189730, 1995.

Yan, N. Q., Liu, S. H., Chang, S. G., and Miller, C.: Method for the study of gaseous oxidants for the oxidation of mercury gas, Ind. Eng. Chem. Res., 44, 5567-5574, doi:10.1021/ie050377j, 2005.

Yan, N. Q., Qu, Z., Chi, Y., Qiao, S. H., Dod, R. L., Chang, S. G., and Miller, C.: Enhanced Elemental Mercury Removal from Coal-Fired Flue Gas by Sulfur-Chlorine Compounds, Environ. Sci. Technol., 43, 5410-5415, doi:10.1021/es801910w, 2009.

Yang, X., Cox, R., Warwick, N., Pyle, J., Carver, G., O'Connor, F., and Savage, N.: Tropospheric bromine chemistry and its impacts on ozone: A model study, J. Geophys. Res.-Atmos., 110, D23311, doi:10.1029/2005jd006244, 2005.

Zhang, H., Fu, X. W., Lin, C.-J., Wang, X., and Feng, X. B.: Observation and analysis of speciated atmospheric mercury in ShangriLa, Tibetan Plateau, China, Atmos. Chem. Phys., 15, 653-665, doi:10.5194/acp-15-653-2015, 2015.

Zhang, Y., Jaeglé, L., van Donkelaar, A., Martin, R. V., Holmes, C. D., Amos, H. M., Wang, Q., Talbot, R., Artz, R., Brooks, S., Luke, W., Holsen, T. M., Felton, D., Miller, E. K., Perry, K. D., Schmeltz, D., Steffen, A., Tordon, R., Weiss-Penzias, P., and Zsolway, R.: Nested-grid simulation of mercury over North America, Atmos. Chem. Phys., 12, 6095-6111, doi:10.5194/acp12-6095-2012, 2012.

Zhang, Y. X., Jacob, D., Dutkiewicz, S., Amos, H., Long, M., and Sunderland, E.: Biogeochemical drivers of the fate of riverine mercury discharged to the global and Arctic oceans, Global Biogeochem. Cy., 29, 854-864, doi:10.1002/2015gb005124, 2015.

Zhang, Y. X., Jacob, D. J., Horowitz, H. M., Chen, L., Amos, H. M., Krabbenhoft, D. P., Slemr, F., St Louis, V. L., and Sunderland, E. M.: Observed decrease in atmospheric mercury explained by global decline in anthropogenic emissions, P. Natl. Acad. Sci. USA, 113, 526-531, doi:10.1073/pnas.1516312113, 2016.

Zheng, W. and Hintelmann, H.: Mercury isotope fractionation during photoreduction in natural water is controlled by its $\mathrm{Hg}$ / DOC ratio, Geochim. Cosmochim. Ac., 73, 6704-6715, doi:10.1016/j.gca.2009.08.016, 2009. 